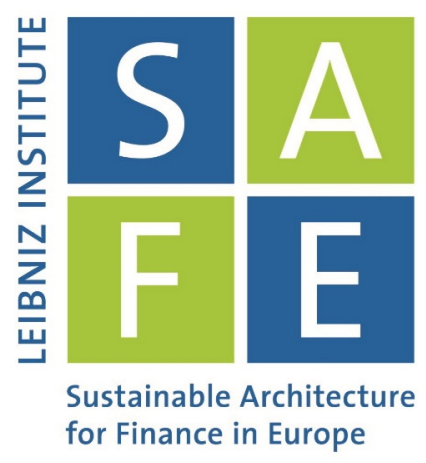

Thomas Pauls

\title{
The Impact of Temporal Framing on the Marginal Propensity to Consume
}

SAFE Working Paper No. 308

\section{Leibniz Institute for Financial Research SAFE}

Sustainable Architecture for Finance in Europe 


\title{
The impact of temporal framing on the marginal propensity to consume*
}

\author{
THOMAS PAULS ${ }^{1}$ \\ Preliminary first draft - do not cite without permission
}

\begin{abstract}
We conducted a large-scale household survey in November 2020 to study how altering the time frame of a message (temporal framing) regarding an imminent positive income shock affects consumption plans. The income shock derives from the abolishment of the German solidarity surcharge on personal income taxes, effective in January 2021. We randomize across survey participants whether their extra disposable income is presented in Euros per month, Euros per year, or Euros per ten year-period. Our main findings are as follows: In General, we find our respondents' intended Marginal Propensity to Consume (MPC) is 28.2\%. Across all three treatments, the MPC is a positive function of age and being female while it is a negative function of the income increase's size, selfcontrol, and being unemployed. Temporal framing effects are statistically and economically highly significant as we find the monthly treatment groups' average MPC 5.6 and 8.7 percentage points higher compared to the yearly and 10-yearly treatment groups. We will be able to analyze the real consumption behavior of households throughout 2021 based on re-surveying the participants as well as by using transaction-based bank data.
\end{abstract}

Keywords: behavioral economics, saving, marginal propensity to consume, tax intervention, tax cut

JEL-Codes: E2, E6

\footnotetext{
I thank Andreas Hackethal and Michael Weber for useful comments and suggestions. Further, I gratefully acknowledge research support from the Leibniz Institute for Financial Research SAFE.

1 Corresponding author. House of Finance, Goethe University Frankfurt, Theodor-W.-Adorno-Platz 3, 60323 Frankfurt am Main, Germany. Pauls@finance.uni-frankfurt.de.
} 


\section{Introduction}

Tax stimuli are powerful tools in the hand of policymakers to overcome times of crisis and recession. The underlying premise of tax interventions as an element of policy design is that households respond to tax-induced income changes. To measure such households responses, researchers draw on the Marginal Propensity to Consume (MPC), which has been proven effective for the evaluation of the macroeconomic impact and effectiveness of tax based interventions (Jappelli \& Pistaferri, 2014).

Contrary to the standard Permanent Income Hypothesis, which predicts a linear consumption function, models that include precautionary savings and liquidity constraints generate a concave consumption function, implying that the MPC is heterogeneous across households (Carroll, 2001, 2009). A common finding of the papers researching MPCs is indeed strong evidence for MPC heterogeneity (e.g. Gelman, 2020 or Jappelli \& Pistaferri, 2020). Elaborating on MPC heterogeneity, recent literature highlights the role that the design of policy interventions can play in constructing more effective stimulus policies. For example, tax cuts framed as "bonus" are more likely spent than tax cuts framed as a "rebate" (e.g., Congdon, Kling, \& Mullainathan, 2009; Epley \& Gneezy, 2007; Epley, Mak, \& Idson, 2006). Other studies highlight the importance of how tax interventions are distributed. Here, tax refunds are more likely spent by the recipients if they are refunded monthly instead of in a lump sum (Shapiro \& Slemrod, 1995, 2003b). Consequently, understanding how household consumption responds to the design and implementation of tax stimuli is an important topic for researchers and policymakers in order to build effective interventions.

In our paper, we study how the temporal framing of a tax cut affects households' consumption, saving, and debt repaying decisions. For that purpose, we use an upcoming tax cut in Germany and conduct a large-scale survey experiment with more than 2,000 clients of a major German retail bank before the introduction of the tax cut. In our experiment, we calculate the respondents' individual prospective income increase from the tax cut and analyze their use of the income increase after showing it to them as either monthly, yearly, or 10-yearly EUR amount.

Respondents in our sample will receive on average EUR 57.11 more per month, which $40.4 \%$ intend to 'mainly spend', $49.2 \%$ to 'mainly save', and $10.4 \%$ to 'mainly repay debt'. 
Thereby, we find significant heterogeneity in the use of the income increases among respondents. Respondents who receive a smaller income increase, i.e. households with either comparably low or comparably high taxable incomes, are less likely to spend the income increase but rather save it. Homeowners as well as older respondents more likely to spend their income increase. On the other side, we find liquidity constrained respondents less likely to save the income increase and more likely to repay debt. Further, we find that respondents with higher levels of self-control are less likely to spend the income increase and more likely to save it, while respondents who are prone to impulsive buying are less likely to save the income increase and more likely to use it for repaying debt.

In addition, we find that temporal framing affects how respondents intend to use their income increase. In particular, we find that the respondents in the yearly and 10-yearly framing groups are 9.2 and 8.0 percentage points less likely to use the income increase to 'mostly increase spending' and 5.9 and 5.1 percentage points more likely to use it to 'mostly increase saving' compared to the respondents in the monthly treatment group.

Looking at the respondents' MPCs, we find that respondents on average intend to spend $28.3 \%$ on non-durable and $11.7 \%$ on non-durable goods. Thereby, non-durable consumption decreases with the income increases' size and respondents' self-control while it increases with the respondents' age. Temporal framing strongly affects the respondents' MPCs. In particular, respondents from the monthly treatment group have a significantly higher nondurable MPC compared to the other groups and allocate 5.6 and 8.7 percentage points more to non-durable consumption compared to the respondents of the yearly and 10-yearly treatment group, respectively. On the other side, respondents from the 10-yearly framing group allocate 4.5 percentage points more to durable consumption compared to the monthly treatment group.

Parallel, we ask the participants how they intend to save their individual income increase. We find that respondents on average allocate $21.1 \%$ of the income increase to risky assets and $10.8 \%$ to savings accounts/ bankbooks, which will yield no significant returns due to commonly low-interest rates. Further, the respondents intend to allocate $5.4 \%$ of the income increase to cash, which will not yield them any return at all. Temporal framing plays a significant role when it comes to the use of risky assets for saving, as we find respondents 
from the monthly treatment group being less likely to use them in the form of one-off investments and somewhat more likely to use them in the form of savings plans.

Our paper adds to two strands of literature. First, it is part of a growing literature that examines the effectiveness of tax interventions on MPC heterogeneity. Shapiro and Slemrod (1995) and Feldman (2010) evaluated the effectiveness of the 1992 decrease in federal income tax withholding. Even though the actual tax rate was unchanged, Shapiro and Slemrod (1995) find an increased propensity to spend out of a reduction in withholding rates and Feldman (2010) finds a decrease in the probability that households contributed to a taxpreferred retirement account. Shapiro and Slemrod (2003a) and Shapiro and Slemrod (2003b) evaluate the role of the Tax Relief Reconciliation Act of 2001 and find that only $21.8 \%$ of the households would the tax rebate to mostly increase spending. Complementary, Johnson, Parker, and Souleles (2006) document that households spent around 20-40\% of their 2001 tax rebate. Evaluating the Economic Stimulus Act 2008 stimulus payments, Sahm, Shapiro, and Slemrod (2010) and Shapiro and Slemrod (2009) find a considerable but small consumption effect. About $20 \%$ of the households implied that they would mostly increase spending but instead would either mostly save the rebate or use it to pay off debt. Parker, Souleles, Johnson, and McClelland (2013) document that households spent on average about $12 \%$ to $30 \%$ of their stimulus payments. Graziani, van der Klaauw, and Zafar (2016) investigate the intended and ex-post spending response to the 2011 pay-roll tax cuts. While respondents in their sample on average intend to spend $14 \%$ of their tax cut, they ex post report spending 36\%. Most recently, Coibion, Gorodnichenko, and Weber (2020) evaluate the effectiveness of the 2020 Coronavirus Aid, Relief, and Economic Security stimulus payments. They find that only $15 \%$ of the households intend to spend most of their transfer payment while $33 \%$ intend to mostly save it and 52\% intend to use it to pay down debt. Other studies approach the subject using hypothetical income shocks (e.g., Christelis, Georgarakos, Jappelli, Pistaferri, \& van Rooij, 2019; Jappelli \& Pistaferri, 2014, 2020). All studies typically find evidence of excess sensitivity of consumption to the income changes induced by tax interventions, with relatively larger responses among low-wealth and low-income 
households, which is consistent with liquidity constraints. ${ }^{2}$ In contrast to those studies, our paper elaborates on MPC heterogeneity considering a permanent positive monthly income shock from a tax cut and evaluating the ex-ante and ex-post self-reported MPC. In general, we find a comparably large ex-ante MPC from the permanent tax cut compared to MPCs from, for example, tax rebates.

Second, a recent strand of the literature considers the role of the tax interventions' design. We add to it by showing how timing affects households' decisions on how to use income increase. Early evidence on the role of the design of tax interventions comes from Epley et al. (2006) and Epley and Gneezy (2007). They highlight the role of tax interventions' framing, as they find that tax cuts framed as "bonus" are more likely spent than tax cuts framed as a "rebate". Shapiro and Slemrod (1995), Feldman (2010), and Chambers and Spencer (2008) find that that the timing of a refund affects its use. Thereby, Shapiro and Slemrod (1995) and Feldman (2010) examine the decrease in U.S. federal income tax withholding from 1992. The intervention only shifted the timing of income tax payments while leaving the ultimate tax burdens unchanged. In particular, households paid less throughout the 1992 tax year but then faced greater liability (or reduced refund) on filing their income tax return in the following year. Shapiro and Slemrod (1995) find the refunds are more likely spent by the recipients if they are refunded monthly instead of in a lump sum. Likewise, Feldman (2010) finds a decrease in the probability that households contributed to a tax-preferred retirement account shifting the tax rebate from a lump-sum to a monthly payment. While the 1992 change in tax withholding left the actual tax burdens unchanged, our paper evaluates the role of framing using an actual tax cut, eliciting the respondents MPC before and after the tax cut becomes effective.

2 For excellent overviews, see Jappelli and Pistaferri (2010, 2014). 


\section{Data}

\subsection{The Solidary surcharge}

The solidarity surcharge was introduced in 1991 as a supplement to the income tax and was originally limited to one year. It was repeatedly extended until today and amounts to $5.5 \%$ of a household's income tax. From 2021 on, the solidarity surcharge is abandoned or at least reduced for most private households depending on their gross income ${ }^{3}$. Figure 1 displays the households' tax rebate from 2021 on with respect to their taxable income.

Households at the lower end of the income distribution, i.e. single households with a taxable income up to EUR 14,532 and couples with a taxable income up to EUR 29,065, did not pay the solidary surcharge and thus do not profit from the tax reduction. Singles with a taxable income up to EUR 61,717 and married couples who tax their incomes jointly with a taxable income up to EUR 123,434 will not have to pay any solidary surcharge from 2021 on. Households with higher taxable incomes up to EUR 96,409 for singles and EUR 192,818 for married couples will fall in a so-called "mitigation-zone", in which the solidary surcharge gradually increases with the households' taxable income. Households with higher taxable incomes will not benefit from the change and will continue to pay the surcharge in full. The households who profit will automatically receive more net of their gross wages with the first monthly salary payment in 2021. According to the German Federal Ministry of Finance (2019), the solidary surcharge will be dismissed entirely for $90.0 \%$ of German households and another $6.5 \%$ will be in the "mitigation-zone".

\subsection{The survey}

We utilize survey data from clients at a major German bank with a national branch network. The clients in our sample are part of a quarterly online survey panel that we started in 2018. For our research, we draw on the November 2020 wave, which is dedicated to our experiment and the upcoming tax reduction. Invitations for the November 2020 wave were sent via E-Mail on November $26^{\text {th }}$. It was designed to take about ten minutes and was

3 The solidarity surcharge is also levied on corporation tax and capital gains tax. For such, the surcharge will remain. 
incentivized using a lottery of fifty EUR 50 online vouchers. In addition to the November wave, we draw on the panels' entrance survey, which every household who enters the panel has to complete. It elicits general information on households' income, (financial) wealth, socio-demographic characteristics, and attitudes as wells as beliefs. To test if the ex-ante made household intentions hold ex-post, we will re-survey the households in our sample at the beginning of 2021 when the tax cut has been in place.

\subsection{Sample Characteristics}

Up to November 26, 5,209 households had completed the entrance survey and were invited to the November wave. 2,048 responded to our survey, which corresponds to a response rate of $39.3 \%$. Of those, we exclude 99 households (4.8\%) who do not complete the November 2020 wave. Appendix 4 shows demographic information for our initial sample and compares it to representative German survey data gathered from the Panel on Household Finances (PHF) dataset by the Deutsche Bundesbank (Kalckreuth, Eisele, Le Blanc, Schmidt, $\&$ Zhu, 2012). Compared to the general population, participants in our sample are more often male, younger, more educated, and earn higher incomes. Further, they possess a higher financial literacy and a lower risk tolerance.

To calculate the expected tax rebate, we asked the respondents for their taxable income as well as whether this income is taxed individually or jointly with a marital partner. Here, 97 $(4.7 \%)$ of the households in our sample refused to report their marital status and 112 households (5.47\%) refused to specify their last year's taxable income. Figure 2 depicts the taxable income distributions among the households in our initial sample whereby Panel A shows the distribution for singles, while Panel B shows the distribution for jointly taxed incomes, i.e. married couples.

Figure 2 shows that the majority of households in our sample is going to profit noticeably from the tax reduction. $67.7 \%$ of the single households report a taxable income between EUR 20,000 and EUR 90,000 and 79.4\% of the married households report a taxable income between EUR 30,000 and EUR 190,000. Figure 3 shows the distribution of the expected tax rebates among households. The vast majority of those households will profit from the tax 
reduction: $81.5 \%$ of the singles and $92.4 \%$ of the couples in our sample will profit from the tax reduction.

As we intend to research the determinants of the tax rebates allocation, we exclude the 217 households $(10.4 \%)$ who will not profit from the solidary surcharge's abolition due to their taxable income being either too high (75 households, 3.6\%) or too low (142 households, $6.8 \%$ ). Our final sample thus comprises 1,524 households. Table 1 presents descriptive statistics for our final sample. On average, the households in our final sample report a taxable income of EUR 66,923 and will save EUR 57.11 from the tax reduction. For the vast majority of our sample, the upcoming tax reduction does not come as a surprise, as only around $21.0 \%$ of the participating households stated that they did not know about it.

\subsection{The experiment}

To test whether temporal framing triggers different consumption, saving, debt repayment, and allocation decisions, we randomly assign the respondents into three groups. The tax rebate is then shown to the participants, whereby it is framed as a monthly amount for group one, a yearly amount for group two, and a 10-yearly amount for group three. ${ }^{4}$ Apart from the differing presentation of the income increase, all survey questions are identical among groups. With the income being shown, we ask the participants how they intend to use the increase in a qualitative manner (Shapiro \& Slemrod, 2003b) or (Coibion et al., 2020). Specifically, we re-show the monthly/ yearly/ 10-yearly income increase to the participants and ask:

"Now that you have an idea of your income increase, how are you going to use it?"

Participants had to choose among "I will mostly save the income increase.", "I will mostly spend the income increase.", or "I will mostly use the increase to repay debt". 5 Following

4 Appendix 5 provides descriptive statistics on our whole sample and the different treatment groups we use in the regression analyses below.

5 See Appendix 3 for an illustration of the qualitative MPC question and how the tax increase was presented to the respondents 
the qualitative question, we repeat the display of the income increase and ask the participants to allocate their income increase in percent using the following question:

"Now that you can estimate your increase, what proportion will you spend, what proportion will you save, and what proportion will you use to repay debts?"

The participants had to allocate 100 percentage points to the options "Share I will spend", "Share I will save", and "Share I will use to repay debt". Households who answered that they would save at least one percent of their income increase were then asked how they would allocate it among different categories.

"How would you allocate the amount you want to save into the following categories?"

The participants had to allocate 100 percentage points to the options "Securities (e.g. stocks or funds) as a one-off investment", "Securities (e.g. stocks or funds) as a savings plan”, “Automated asset management ("Robo-Advisor")”, "Pension/capital life insurance”, "Riester/ Rürup pension plan", "Savings account/ bankbook”, "Cash", and "Other". Further, respondents who answered that they would spend at least one percent of their income increase were asked how they would allocate it among the following categories.

"How would you allocate the amount you want to spend into the following categories?"

The participants had to allocate 100 percentage points to the options "Vacation, traveling, going to a restaurant or other leisure activities", "Donations/ gifts", "General cost of living”, "Larger purchases worth $€ 1,000$ or less (e.g. Electrical appliances, sports equipment, clothing, ...)”, "Repairs/ renovations (e.g. of vehicles or real estate)”, “Own education/ education of members of the household", "Larger purchases worth more than $€$

6 Riester/ Rürup pension plans are state-subsidized and pension plans, for more information, refer to Meyll, Pauls, and Walter (2020) or Börsch-Supan, Bucher-Koenen, Goll, and Maier (2016). 
1,000 (e.g. cars, ...)", and "Others". Appendix 2 provides more details on the just described dependent variables of our analyses.

\section{Descriptive analyses}

\subsection{How do households intend to use the income increase?}

Panel A of Table 2 reports the households' answers to the qualitative MPC question. Column (1) shows the answers for our whole sample while columns (2) to (4) present the answers for the monthly, yearly, and 10-yearly treatment groups. With respect to the qualitative question, roughly half $(49.2 \%)$ of the respondents mostly want to save the income increase while $40.4 \%$ report that they mostly want to spend the increase. Repaying debt only plays a minor role for the households in our sample as only $10.4 \%$ intend to use the increase mostly to repay debt. Table 2 also provides first descriptive evidence in favor of our hypothesis. Looking at the qualitative answers with respect to the different treatment groups, Panel A of Table 2 shows that the share of households who intend to mostly spend the income increase decreases with the temporal framing from monthly to 10-yearly while the share of households who intend to mostly spend the increase decreases. In particular, $47.8 \%$ of the monthly-treatment group report that they intend to mostly use the increase for consumption, while only $37.0 \%$ and $36.6 \%$ if the yearly and 10 -yearly treatment groups do so. In contrast, only $43.5 \%$ of the monthly treatment group report that they intend to use the income increase to mostly increase saving, while $51.3 \%$ and $52.6 \%$ of the yearly and 10 -yearly treatment group do so. The share of households who intend to use the income increase mostly to repay debt is also lowest for the monthly treatment group $(8.7 \%)$ and is moderately higher for the yearly $(11.7 \%)$ and 10-yearly (10.8\%) treatment groups. Panel B of Table 2 shows the corresponding results for the quantitative MPC question and essentially confirms the just described results from the qualitative question.

Looking deeper into the quantitative MPC question, Figure 4 plots the distribution of the income increase allocations. Looking at consumption, $22.7 \%$ of the respondents do not want to spend any share of the income increase while $20.2 \%$ intend to spend the entire increase. For saving, $26.6 \%$ of the respondents report that they will save nothing from their income 
increase while $17.0 \%$ will save the entire increase. ${ }^{7}$ Figure 4 also shows 'heaping' at rounded values $(10 \%, 20 \%$, etc.). However, heaping at ' $50 \%$ ', which is often interpreted as indicating respondent indecisiveness, is low in our sample. Only $9.0 \%$ of the spending, $9.4 \%$ of the saving, and $2.4 \%$ of the repaying debt answers were ' $50 \%$ '. In comparison, Jappelli and Pistaferri (2020) find around one-fourth of their answers heaping at '50\%'. As our respondents are offered three categories for allocation, choosing '33\%' might reflect the respondents' indecisiveness rather than choosing ' $50 \%$ '. However, we find no heaping towards the '33\%' in our sample as less than 1\% of the respondents chose the '33\%' option. We take this as an indication that the responses in our sample are reliable.

\subsection{How do households intend to save/ spend the income increase?}

Panel B of Table 2 reports the respondents' allocations of their income increase to the quantitative categories. When it comes to how respondents spend their income increase, Panel B of Table 2 shows that the 'costs of living' represent the most important consumption category. In particular, the respondents in our sample intend to allocate $15.5 \%$ of their income increases here. Adding the allocations to the 'vacation' (10.3\%) and 'donation/gift' (2.5\%) categories, the MPC from non-durable consumption amounts to $28.3 \%$. The allocation to durable goods amounts to $11.7 \%$, whereby the most important categories are represented by 'reparation \& renovation' (4.7\%), and 'durable goods < EUR 1,000' (3.9\%). The other categories play only minor roles. Thereby, the allocation of the income increase seems to be strongly related to temporal framing. For example, respondents from the monthly treatment group allocate $21.7 \%$ of their income increases to 'costs of living', the respondents from the yearly and 10-yearly treatment groups intend to allocate less, namely $14.3 \%$ and $10.6 \%$, respectively. On the other hand, allocation to the categories 'vacation', 'reparation \& renovation', and 'durable goods > EUR 1,000' seems to increase from monthly to 10-yearly temporal framing.

Looking at the allocation to different saving vehicles, we find that 'risky assets' represent the most important. In particular, the respondents in our whole sample (column (1)) intend

\footnotetext{
${ }^{7}$ For repaying debt, $76.8 \%$ of the respondents indicate that they will not allocate any of their income increase.
} 
to allocate $10.7 \%$ of the income increase to 'risky assets as one-time investment' and another $10.4 \%$ to 'risky assets as savings plans'. Although there will be no significant returns due to commonly low-interest rates, the respondents in our sample intend to allocate $10.8 \%$ to 'savings accounts'. Further, the respondents intend to save $5.4 \%$ of the income increase in 'cash', which will not yield them any return. Interestingly, classical 'pension insurances' as well as modern 'Robo-advisors' do not play a significant role in the respondents' intentions to allocate their income increases. Looking at the effect of temporal framing (columns (2) to (4)), we find that the allocation to 'risky assets as one-time investment' seems to be strongly affected. In particular, respondents to which the income increase was shown in a monthly manner intend to allocate $7.0 \%$ to risky assets as a one-time investment while respondents to which the increase was shown in a 10 -yearly manner intend to allocate $12.7 \%$.

\section{Regression results}

\subsection{Does temporal framing affect how respondents use the income increase?}

To multivariately test whether temporal framing affects households' use of a permanent income increase, we estimate a series of Probit regression models of the following form:

$$
D_{j, i}=\alpha+\beta_{1} \text { TreatmentGroup }+\delta^{\prime} X_{i}+\epsilon_{i}
$$

Where $D_{j, i}$ is a set of binary variables equal to one if a respondent $i$ indicates to use the permanent income increase to 'mostly increase spending', 'mostly increase saving', or 'mostly repay debt', respectively. ${ }^{8}$ TreatmentGroup $_{i}$ represents a categorical variable indicating if respondent $i$ is in the monthly, yearly, or 10-yearly treatment group. In the regression models, respondents in the monthly group are omitted. To mitigate potential confounding effects, we include a battery of demographic and income shock-related control variables as well as several measures of the respondents' preferences and attitudes in vector $X_{i}$. For the exact definition of the variables, please refer to Appendix 1 and Appendix 2.

\footnotetext{
8 Appendix 2 shows the definitions of our dependent variables.
} 
Table 3 reports average marginal effects from just described Probit models and provides evidence for our hypothesis that temporal framing affects the respondents' use of the income increase. Compared to the respondents in the monthly treatment group, which is the baseline in our models, the respondents in the yearly and 10-yearly framing groups are 9.2 percentage points and 8.0 percentage points less likely to use the income increase to 'mostly increase spending' (column (1)). Further, the respondents in the yearly and 10-yearly framing groups are 5.9 percentage points and 5.1 percentage points more likely to use the income increase to 'mostly increase saving' compared to the respondents in the monthly treatment group (column (2)). When it comes to using the income increase to 'mostly repay debt', we find a 3.5 percentage points higher probability to choose that option for respondents in the yearly treatment group compared to the respondents in the monthly treatment group. However, this effect is only borderline significant at the $10 \%$-level. To ensure that this effect is actually due to the framing and not to the income increases' actual (monthly) size, we include the monthly logged income increase to our models. We find the income increase to significantly reduce the probability that the respondents use the increase for spending and to significantly increase the probability that the respondent will use it to increase saving. Interestingly, we do not find the tax cut being unanticipated to affect their decision on how to use it. Rather, proxies of their wealth and liquidity seem to play a role. Homeowners and respondents with lower incomes are significantly less likely to save and more likely to mostly spend the income increase. Households who have no 'rainy day savings' are less likely to save the income increase and more likely to use it to repay debt

Several other observable factors significantly affect how respondents use their income increases. For example, older respondents are less likely to save the income increase and rather spend it compared to younger respondents. Looking at respondents' preferences and attitudes, respondents who are more prone to impulsive buying behavior are less likely to mostly save the income increase while they are more likely to mostly use it to repay debt. Thereby, the latter might be a result of impulsive buyers being more likely to take on debt in the first place as found by, for example, Gathergood and Weber (2014). Respondents with higher self-control are less likely to spend the income increase, while they are more likely to mostly save it. 
4.2. Does temporal framing affect how respondents spend/ save the income increase?

We perform analyses on how the respondents intend to spend and save the income increase, respectively.

For allocation of the income increase to spending categories, we estimate a series of OLS regression models of the following form:

$$
C_{j, i}=\alpha+\beta_{1} \text { TreatmentGroup }+\delta^{\prime} X_{i}+\epsilon_{i}
$$

Where $C_{j, i}$ is a set of variables containing respondent $i$ 's allocation of the income increase to the consumption category $j$. The allocation options were "General cost of living", "Larger purchases worth EUR 1,000 or less (e.g. Electrical appliances, sports equipment, clothing, ...)”, "Larger purchases worth more than EUR 1,000 (e.g. cars, ...)”, "Repairs/ renovations (e.g. of vehicles or real estate)", “Own education/ education of members of the household”, "Donations/ gifts", "Vacation, traveling, going to a restaurant or other leisure activities", and "Others". In Table 4 column 1, we summarize the categories "General cost of living”, "Donations/ gifts", and "Vacation, traveling, going to a restaurant or other leisure activities" to non-durable consumption, and "Larger purchases worth EUR 1,000 or less (e.g. Electrical appliances, sports equipment, clothing, ...)”, "Larger purchases worth more than EUR 1,000 (e.g. cars, ...)”, “Repairs/ renovations (e.g. of vehicles or real estate)”, and "Own education/ education of members of the household" to durable consumption. In Table 5 , we use the categories separately. For the allocation to saving categories, we estimate a series of OLS regression models of the following form:

$$
S_{j, i}=\alpha+\beta_{1} \text { TreatmentGroup }+\delta^{\prime} X_{i}+\epsilon_{i}
$$

Where $S_{j, i}$ is a set of variables containing respondent $i$ 's allocation of the income increase to the saving vehicle $j$. The allocation options were "Securities (e.g. stocks or funds) as a one-off investment”, "Securities (e.g. stocks or funds) as a savings plan”, "Automated asset management ('Robo-Advisor')”, “Pension/ capital life insurance”, “Riester/Rürup pension 
plan", "Savings account/ 'Sparbuch", "Cash", and "Other",. As in previous regression analyses, we include TreatmentGroup $i$ as a categorical variable indicating if respondent $i$ is in the monthly, yearly, or 10-yearly treatment group and omit the monthly treatment group to use it as baseline category. Also as in previous regression analyses, we include the vector $X_{i}$, which includes a battery of demographic and income shock-related control variables as well as several measures of the respondents' preferences and attitudes. The analyses' results are presented in Table 6.

Looking at the determinants of non-durable and durable consumption, Table 4 shows great heterogeneity among the respondents in our sample. Male respondents, respondents with a higher income, and respondents with higher self-control allocate significantly lower shares to non-durable consumption (column (1)). On the other side, older respondents and respondents with a higher risk tolerance allocate a larger share of their income increase to non-durable consumption. Table 4 also shows that temporal framing significantly affects the respondents' MPC. In particular, respondents from the monthly treatment group allocate 5.6 and 8.7 percentage points more to non-durable consumption compared to the respondents of the yearly and 10-yearly treatment group, respectively. On the other side, respondents from the 10 -yearly framing group allocate 4.5 percentage points more to durable consumption compared to the monthly treatment group.

Going more into detail, Table 5 shows how temporal framing affects the respondents' allocation of the income increase to the non-aggregated consumption categories. Most notably, respondents who have been displayed the income increase yearly and 10-yearly compared to monthly allocate 6.7 and 9.7 percentage points less to the cost of living, respectively (column (1)). The results hold after controlling for the size of the income increase, which is strongly negatively related to allocating the income increase to the cost of living. In addition, temporal framing plays a role when it comes to durable goods smaller and larger than EUR 1,000 (columns (2) and (3)). Here, we do not find a statistically different allocation between the respondents in the monthly and yearly treatment group. However, compared to those in the monthly treatment group, the respondents in the 10 -yearly treatment

\footnotetext{
9 Appendix 2 shows the definitions of our dependent variables.
} 
group are significantly more likely to allocate shares of their income increase into these categories.

Table 6 presents regression results on how temporal framing affects the respondents' allocation of their income increase. Temporal framing has the most notable effect on securities as a one-off investment. In particular, respondents in the yearly and 10-yearly framing groups allocate 5.1 and 5.0 percentage points more into securities as a one-off investment compared to respondents in the monthly treatment group (column (1)). On the other side, respondents in the monthly treatment group allocate 2.9 percentage points more into risky assets as savings plans, whereby the effect is only significant at the $10 \%$-level (column (2)).

\section{Conclusion}

We use a large-scale survey of German retail bank customers and study how temporal framing from an income tax cut affects households' consumption, saving, and debt repay decisions. We draw on an income tax cut in Germany to explore heterogeneity in the use of the income increase. We find large positive consumption responses for older respondents, homeowners, and households with self-control issues. Also, we find that the reported spending decreases with the size of the income increase and we find strong heterogeneity in the specific allocation to spending and saving categories. In general, we find a $28.2 \%$. exante non-durable MPC from the permanent tax cut.

The main aspect of our paper is to investigate how households allocate their income increase depending on temporal framing, meaning whether the increase is presented in a monthly, yearly, or 10-yearly manner. We find that the increase's temporal framing strongly affects its usage. Monthly payments are more likely spent compared to income increases that were framed yearly or 10-yearly. Likewise, temporal framing affects the allocation of the income increase into spending categories and saving vehicles. In particular, the income increase is less likely allocated to the cost of living if the income increase is presented monthly. Further, the income increase is more like allocated to larger durable goods (more than EUR 1,000) if presented in a 10-yearly manner. Looking at the allocation to saving 
vehicles, our results show that respondents allocate less to risky assets as a once-off investment if the income increase is presented monthly.

Our paper highlights that the design of tax interventions is important to achieve the desired public policy and that temporal framing is an important determinant of households' use of tax increases. Other yet to be explored aspects of the design might be equally important in order to create efficient policy interventions. 


\section{Tables}

Table 1: Sample descriptive statistics

\begin{tabular}{lcccccc}
\hline \hline Sample Statistics & Mean & SD & Min & Median & Max & $\mathrm{N}$ \\
\hline Age & 50.88 & 15.08 & 22.00 & 51.00 & 95.00 & 1,523 \\
Male & 0.69 & 0.47 & 0.00 & 1.00 & 1.00 & 1,524 \\
Married & 0.60 & 0.49 & 0.00 & 1.00 & 1.00 & 1,524 \\
Household size & 2.37 & 1.00 & 1.00 & 2.00 & 4.00 & 1,524 \\
Taxable income & 66,923 & 34,339 & 20,000 & 60,000 & 190,000 & 1,524 \\
Income increase & 57.11 & 36.89 & 3.77 & 47.55 & 148.80 & 1,524 \\
Tax cut unanticipated & 0.21 & 0.40 & 0.00 & 0.00 & 1.00 & 1,524 \\
College & 0.50 & 0.50 & 0.00 & 1.00 & 1.00 & 1,524 \\
Retired & 0.17 & 0.37 & 0.00 & 0.00 & 1.00 & 1,524 \\
Self-employed & 0.06 & 0.24 & 0.00 & 0.00 & 1.00 & 1,524 \\
Unemployed & 0.02 & 0.13 & 0.00 & 0.00 & 1.00 & 1,524 \\
Homeowner & 0.56 & 0.50 & 0.00 & 1.00 & 1.00 & 1,524 \\
Financial literacy score & 2.67 & 0.69 & 0.00 & 3.00 & 3.00 & 1,524 \\
Risk tolerance & 3.47 & 1.51 & 1.00 & 4.00 & 7.00 & 1,524 \\
Patience & 4.70 & 1.63 & 1.00 & 5.00 & 7.00 & 1,524 \\
Rainy day savings - none & 0.19 & 0.39 & 0.00 & 0.00 & 1.00 & 1,524 \\
Rainy day savings - na & 0.04 & 0.21 & 0.00 & 0.00 & 1.00 & 1,524 \\
Impulsive buying & 1.95 & 1.33 & 1.00 & 1.00 & 7.00 & 1,524 \\
Self-control & 5.18 & 1.46 & 1.00 & 5.00 & 7.00 & 1,524 \\
\hline
\end{tabular}

Table 2: Use of tax rebate

\begin{tabular}{|c|c|c|c|c|c|c|c|c|}
\hline \multirow[t]{2}{*}{ Sample Statistics } & \multicolumn{2}{|c|}{ Whole Sample } & \multicolumn{2}{|c|}{ Treat: Monthly } & \multicolumn{2}{|c|}{ Treat: Yearly } & \multicolumn{2}{|c|}{ Treat: 10-yearly } \\
\hline & Mean & SD & Mean & SD & Mean & SD & Mean & SD \\
\hline \multicolumn{9}{|l|}{ Panel A: Qualitative MPC } \\
\hline Spending (qual.) & 0.404 & 0.491 & 0.478 & 0.500 & 0.370 & 0.483 & 0.366 & 0.482 \\
\hline Saving (qual.) & 0.492 & 0.500 & 0.435 & 0.496 & 0.513 & 0.500 & 0.526 & 0.500 \\
\hline Repay debt (qual.) & 0.104 & 0.306 & 0.087 & 0.283 & 0.117 & 0.322 & 0.108 & 0.311 \\
\hline \multicolumn{9}{|l|}{ Panel B: Quantitative MPC } \\
\hline Spending (quant.) & 0.442 & 0.380 & 0.496 & 0.413 & 0.422 & 0.370 & 0.410 & 0.349 \\
\hline Non-durable consumption & 0.282 & 0.338 & 0.340 & 0.380 & 0.274 & 0.325 & 0.236 & 0.299 \\
\hline Cost of living & 0.155 & 0.284 & 0.217 & 0.341 & 0.143 & 0.271 & 0.106 & 0.221 \\
\hline Vacation & 0.103 & 0.206 & 0.096 & 0.211 & 0.102 & 0.203 & 0.111 & 0.206 \\
\hline Donation/ Gift & 0.025 & 0.090 & 0.027 & 0.101 & 0.028 & 0.095 & 0.019 & 0.070 \\
\hline Durable consumption & 0.117 & 0.204 & 0.100 & 0.209 & 0.107 & 0.200 & 0.141 & 0.200 \\
\hline Durable goods $<$ EUR 1,000 & 0.039 & 0.118 & 0.031 & 0.116 & 0.042 & 0.134 & 0.043 & 0.103 \\
\hline Durable goods >EUR 1,000 & 0.019 & 0.077 & 0.013 & 0.068 & 0.010 & 0.061 & 0.032 & 0.096 \\
\hline Reparation/ Renovation & 0.047 & 0.133 & 0.046 & 0.146 & 0.043 & 0.131 & 0.053 & 0.121 \\
\hline Education & 0.012 & 0.056 & 0.010 & 0.065 & 0.012 & 0.049 & 0.014 & 0.053 \\
\hline Other & 0.044 & 0.154 & 0.056 & 0.190 & 0.041 & 0.140 & 0.035 & 0.126 \\
\hline Saving (quant.) & 0.447 & 0.379 & 0.410 & 0.403 & 0.464 & 0.373 & 0.466 & 0.359 \\
\hline Risky assets & 0.107 & 0.242 & 0.070 & 0.217 & 0.121 & 0.260 & 0.127 & 0.242 \\
\hline Risky assets (plan) & 0.104 & 0.233 & 0.112 & 0.270 & 0.086 & 0.210 & 0.114 & 0.214 \\
\hline Robo advisor & 0.008 & 0.056 & 0.006 & 0.056 & 0.009 & 0.066 & 0.008 & 0.044 \\
\hline Pension Insurance & 0.017 & 0.083 & 0.016 & 0.085 & 0.017 & 0.080 & 0.020 & 0.085 \\
\hline Riester/ Rürup & 0.008 & 0.059 & 0.007 & 0.054 & 0.004 & 0.026 & 0.012 & 0.083 \\
\hline Savings Account & 0.108 & 0.231 & 0.105 & 0.244 & 0.119 & 0.241 & 0.101 & 0.207 \\
\hline Cash & 0.054 & 0.148 & 0.048 & 0.147 & 0.068 & 0.169 & 0.046 & 0.123 \\
\hline Other & 0.041 & 0.140 & 0.045 & 0.151 & 0.039 & 0.135 & 0.038 & 0.134 \\
\hline Repaying debt (quant.) & 0.111 & 0.257 & 0.094 & 0.248 & 0.115 & 0.259 & 0.124 & 0.262 \\
\hline Observations & \multicolumn{2}{|c|}{1,524} & \multicolumn{2}{|c|}{492} & \multicolumn{2}{|c|}{513} & \multicolumn{2}{|c|}{519} \\
\hline
\end{tabular}


Table 3: Regression Analyses: Use of tax rebate (Probit Regressions)

\begin{tabular}{|c|c|c|c|}
\hline Treat: Yearly & $\begin{array}{c}-0.092^{* * *} \\
(0.029)\end{array}$ & $\begin{array}{l}0.059^{\star *} \\
(0.030)\end{array}$ & $\begin{array}{l}0.035^{*} \\
(0.018)\end{array}$ \\
\hline Treat: $10-$ Yearly & $\begin{array}{c}-0.080^{\star \star \star} \\
(0.029)\end{array}$ & $\begin{array}{l}0.051^{*} \\
(0.030)\end{array}$ & $\begin{array}{c}0.028 \\
(0.018)\end{array}$ \\
\hline Taxable income (log) & $\begin{array}{l}-0.076^{\star} \\
(0.041)\end{array}$ & $\begin{array}{l}0.077^{*} \\
(0.043)\end{array}$ & $\begin{array}{l}-0.006 \\
(0.033)\end{array}$ \\
\hline Income increase (log) & $\begin{array}{c}-0.053^{* *} \\
(0.022)\end{array}$ & $\begin{array}{l}0.044^{*} \\
(0.023)\end{array}$ & $\begin{array}{c}0.018 \\
(0.018)\end{array}$ \\
\hline Tax cut unanticipated & $\begin{array}{c}-0.005 \\
(0.030)\end{array}$ & $\begin{array}{l}-0.010 \\
(0.031)\end{array}$ & $\begin{array}{c}0.014 \\
(0.018)\end{array}$ \\
\hline Male & $\begin{array}{l}-0.025 \\
(0.028)\end{array}$ & $\begin{array}{c}0.019 \\
(0.028)\end{array}$ & $\begin{array}{c}0.009 \\
(0.017)\end{array}$ \\
\hline Household size & $\begin{array}{c}0.006 \\
(0.014)\end{array}$ & $\begin{array}{c}-0.029^{\star *} \\
(0.014)\end{array}$ & $\begin{array}{l}0.021^{* *} \\
(0.009)\end{array}$ \\
\hline Married & $\begin{array}{l}0.056^{\star} \\
(0.032)\end{array}$ & $\begin{array}{c}-0.076^{* *} \\
(0.032)\end{array}$ & $\begin{array}{c}0.023 \\
(0.021)\end{array}$ \\
\hline Age & $\begin{array}{c}0.017^{* * *} \\
(0.005)\end{array}$ & $\begin{array}{c}-0.018^{* * *} \\
(0.006)\end{array}$ & $\begin{array}{c}0.004 \\
(0.004)\end{array}$ \\
\hline $\mathrm{Age}^{2}$ & $\begin{array}{c}-0.000^{* *} \\
(0.000)\end{array}$ & $\begin{array}{l}0.000^{* *} \\
(0.000)\end{array}$ & $\begin{array}{l}-0.000 \\
(0.000)\end{array}$ \\
\hline College & $\begin{array}{l}-0.013 \\
(0.024)\end{array}$ & $\begin{array}{l}-0.016 \\
(0.025)\end{array}$ & $\begin{array}{c}0.024 \\
(0.016)\end{array}$ \\
\hline Retired & $\begin{array}{c}0.054 \\
(0.042)\end{array}$ & $\begin{array}{l}-0.078^{*} \\
(0.044)\end{array}$ & $\begin{array}{c}0.018 \\
(0.032)\end{array}$ \\
\hline Self-employed & $\begin{array}{c}0.016 \\
(0.049)\end{array}$ & $\begin{array}{l}-0.025 \\
(0.051)\end{array}$ & $\begin{array}{c}0.009 \\
(0.031)\end{array}$ \\
\hline Unemployed & $\begin{array}{l}-0.067 \\
(0.094)\end{array}$ & $\begin{array}{c}0.004 \\
(0.097)\end{array}$ & $\begin{array}{c}0.055 \\
(0.053)\end{array}$ \\
\hline Homeowner & $\begin{array}{l}0.065^{\star \star} \\
(0.027)\end{array}$ & $\begin{array}{c}-0.083^{\star * *} \\
(0.028)\end{array}$ & $\begin{array}{c}0.020 \\
(0.019)\end{array}$ \\
\hline Financial literacy score & $\begin{array}{c}0.011 \\
(0.018)\end{array}$ & $\begin{array}{c}0.008 \\
(0.019)\end{array}$ & $\begin{array}{l}-0.017 \\
(0.011)\end{array}$ \\
\hline Risk tolerance & $\begin{array}{l}-0.005 \\
(0.009)\end{array}$ & $\begin{array}{c}0.013 \\
(0.009)\end{array}$ & $\begin{array}{l}-0.008 \\
(0.005)\end{array}$ \\
\hline Patience & $\begin{array}{l}-0.004 \\
(0.008)\end{array}$ & $\begin{array}{c}0.004 \\
(0.008)\end{array}$ & $\begin{array}{l}-0.000 \\
(0.005)\end{array}$ \\
\hline Impulsive buying & $\begin{array}{c}0.014 \\
(0.009)\end{array}$ & $\begin{array}{c}-0.040^{* * *} \\
(0.010)\end{array}$ & $\begin{array}{c}0.021^{* * *} \\
(0.006)\end{array}$ \\
\hline Self-control & $\begin{array}{c}-0.040^{\star * *} \\
(0.008)\end{array}$ & $\begin{array}{c}0.034^{* * *} \\
(0.009)\end{array}$ & $\begin{array}{c}0.005 \\
(0.005)\end{array}$ \\
\hline Rainy day savings - none & $\begin{array}{c}0.047 \\
(0.033)\end{array}$ & $\begin{array}{c}-0.104^{\star \star \star *} \\
(0.033)\end{array}$ & $\begin{array}{c}0.051^{* * *} \\
(0.020)\end{array}$ \\
\hline Rainy day savings - na & $\begin{array}{c}0.005 \\
(0.059)\end{array}$ & $\begin{array}{c}0.030 \\
(0.060)\end{array}$ & $\begin{array}{l}-0.023 \\
(0.042)\end{array}$ \\
\hline $\begin{array}{l}\text { Observations } \\
\text { Chi }^{2} \\
\text { p-value }\end{array}$ & $\begin{array}{l}1523 \\
194.1 \\
0.000\end{array}$ & $\begin{array}{l}1523 \\
181.8 \\
0.000\end{array}$ & $\begin{array}{l}1523 \\
82.6 \\
0.000\end{array}$ \\
\hline
\end{tabular}


Table 4: Regression Analyses: Non-durable and durable consumption

\begin{tabular}{|c|c|c|}
\hline Sample Statistics & $\begin{array}{c}\text { Non-durable consumption } \\
\text { (1) }\end{array}$ & $\begin{array}{c}\text { Durable consumption } \\
\text { (2) }\end{array}$ \\
\hline Treat: Yearly & $\begin{array}{l}-0.056^{\star \star *} \\
(0.021)\end{array}$ & $\begin{array}{c}0.008 \\
(0.013)\end{array}$ \\
\hline Treat: 10 -Yearly & $\begin{array}{c}-0.087^{* * *} \\
(0.021)\end{array}$ & $\begin{array}{c}0.045^{\star \star \star *} \\
(0.013)\end{array}$ \\
\hline Taxable income (log) & $\begin{array}{l}-0.038 \\
(0.031)\end{array}$ & $\begin{array}{c}-0.037^{* *} \\
(0.017)\end{array}$ \\
\hline Income increase (log) & $\begin{array}{c}-0.066^{* * *} \\
(0.018)\end{array}$ & $\begin{array}{l}0.018^{\star} \\
(0.010)\end{array}$ \\
\hline Tax cut unanticipated & $\begin{array}{l}-0.006 \\
(0.020)\end{array}$ & $\begin{array}{c}0.018 \\
(0.014)\end{array}$ \\
\hline Male & $\begin{array}{c}-0.071^{* * *} \\
(0.019)\end{array}$ & $\begin{array}{c}0.019 \\
(0.012)\end{array}$ \\
\hline Household size & $\begin{array}{c}0.011 \\
(0.009)\end{array}$ & $\begin{array}{c}0.007 \\
(0.006)\end{array}$ \\
\hline Married & $\begin{array}{c}0.027 \\
(0.023)\end{array}$ & $\begin{array}{c}0.014 \\
(0.013)\end{array}$ \\
\hline Age & $\begin{array}{l}0.010^{\star *} \\
(0.004)\end{array}$ & $\begin{array}{l}0.004^{\star} \\
(0.002)\end{array}$ \\
\hline $\mathrm{Age}^{2}$ & $\begin{array}{l}-0.000 \\
(0.000)\end{array}$ & $\begin{array}{l}-0.000 \\
(0.000)\end{array}$ \\
\hline College & $\begin{array}{l}-0.012 \\
(0.017)\end{array}$ & $\begin{array}{c}0.008 \\
(0.011)\end{array}$ \\
\hline Retired & $\begin{array}{c}0.003 \\
(0.036)\end{array}$ & $\begin{array}{l}-0.003 \\
(0.023)\end{array}$ \\
\hline Self-employed & $\begin{array}{c}0.030 \\
(0.036)\end{array}$ & $\begin{array}{l}-0.021 \\
(0.021)\end{array}$ \\
\hline Unemployed & $\begin{array}{l}-0.136^{\star *} \\
(0.064)\end{array}$ & $\begin{array}{c}0.027 \\
(0.049)\end{array}$ \\
\hline Homeowner & $\begin{array}{c}0.007 \\
(0.019)\end{array}$ & $\begin{array}{c}0.019 \\
(0.012)\end{array}$ \\
\hline Financial literacy score & $\begin{array}{c}0.019 \\
(0.013)\end{array}$ & $\begin{array}{c}0.000 \\
(0.009)\end{array}$ \\
\hline Risk tolerance & $\begin{array}{l}0.013^{\star *} \\
(0.006)\end{array}$ & $\begin{array}{l}-0.007^{\star} \\
(0.004)\end{array}$ \\
\hline Patience & $\begin{array}{c}0.005 \\
(0.005)\end{array}$ & $\begin{array}{c}0.001 \\
(0.003)\end{array}$ \\
\hline Impulsive buying & $\begin{array}{l}0.013^{\star} \\
(0.007)\end{array}$ & $\begin{array}{c}0.004 \\
(0.004)\end{array}$ \\
\hline Self-control & $\begin{array}{c}-0.029^{* * *} \\
(0.006)\end{array}$ & $\begin{array}{l}-0.003 \\
(0.004)\end{array}$ \\
\hline Rainy day savings - none & $\begin{array}{l}-0.014 \\
(0.022)\end{array}$ & $\begin{array}{c}0.012 \\
(0.015)\end{array}$ \\
\hline Rainy day savings - na & $\begin{array}{l}-0.021 \\
(0.034)\end{array}$ & $\begin{array}{c}0.027 \\
(0.028)\end{array}$ \\
\hline Constant & $\begin{array}{l}0.684^{\star *} \\
(0.297)\end{array}$ & $\begin{array}{l}0.301^{*} \\
(0.166)\end{array}$ \\
\hline $\begin{array}{l}\text { Observations } \\
\mathrm{R}^{2}\end{array}$ & $\begin{array}{l}1,514 \\
0.134\end{array}$ & $\begin{array}{l}1,514 \\
0.030\end{array}$ \\
\hline
\end{tabular}


Table 5: Regression Analyses: Use of tax rebate (Consumption categories)

\begin{tabular}{|c|c|c|c|c|c|c|c|c|}
\hline Sample Statistics & $\frac{\text { Cost of living }}{(1)}$ & $\begin{array}{c}\begin{array}{c}\text { Durable } \\
\text { goods } \\
<\text { EUR 1,000 }\end{array} \\
(2)\end{array}$ & $\begin{array}{c}\begin{array}{c}\text { Durable } \\
\text { goods } \\
\text { >EUR 1,000 }\end{array} \\
(3)\end{array}$ & $\begin{array}{c}\begin{array}{c}\text { Reparation / } \\
\text { Renovation }\end{array} \\
(4)\end{array}$ & $\frac{\text { Education }}{(5)}$ & $\begin{array}{c}\begin{array}{c}\text { Donation / } \\
\text { Gift }\end{array} \\
(6)\end{array}$ & $\frac{\text { Vacation }}{(7)}$ & $\begin{array}{c}\text { Other } \\
(8)\end{array}$ \\
\hline Treat: Yearly & $\begin{array}{c}-0.067^{* * *} \\
(0.019)\end{array}$ & $\begin{array}{c}0.011 \\
(0.008)\end{array}$ & $\begin{array}{l}-0.003 \\
(0.004)\end{array}$ & $\begin{array}{l}-0.002 \\
(0.009)\end{array}$ & $\begin{array}{c}0.001 \\
(0.004)\end{array}$ & $\begin{array}{c}0.002 \\
(0.006)\end{array}$ & $\begin{array}{c}0.009 \\
(0.013)\end{array}$ & $\begin{array}{l}-0.014 \\
(0.010)\end{array}$ \\
\hline Treat: 10 -Yearly & $\begin{array}{c}-0.097^{\star * *} \\
(0.017)\end{array}$ & $\begin{array}{l}0.012^{*} \\
(0.007)\end{array}$ & $\begin{array}{c}0.020^{\star \star *} \\
(0.005)\end{array}$ & $\begin{array}{c}0.010 \\
(0.008)\end{array}$ & $\begin{array}{c}0.004 \\
(0.004)\end{array}$ & $\begin{array}{l}-0.007 \\
(0.006)\end{array}$ & $\begin{array}{c}0.017 \\
(0.013)\end{array}$ & $\begin{array}{c}-0.020^{\star \star} \\
(0.010)\end{array}$ \\
\hline Taxable income (log) & $\begin{array}{l}-0.022 \\
(0.026)\end{array}$ & $\begin{array}{l}-0.005 \\
(0.010)\end{array}$ & $\begin{array}{l}-0.003 \\
(0.007)\end{array}$ & $\begin{array}{c}-0.023^{* *} \\
(0.010)\end{array}$ & $\begin{array}{l}-0.006 \\
(0.005)\end{array}$ & $\begin{array}{l}-0.009 \\
(0.008)\end{array}$ & $\begin{array}{l}-0.007 \\
(0.022)\end{array}$ & $\begin{array}{l}-0.004 \\
(0.011)\end{array}$ \\
\hline Income increase (log) & $\begin{array}{c}-0.077^{\star \star *} \\
(0.016)\end{array}$ & $\begin{array}{c}0.001 \\
(0.006)\end{array}$ & $\begin{array}{l}0.006^{\star \star} \\
(0.003)\end{array}$ & $\begin{array}{c}0.010 \\
(0.006)\end{array}$ & $\begin{array}{c}0.001 \\
(0.003)\end{array}$ & $\begin{array}{c}0.002 \\
(0.004)\end{array}$ & $\begin{array}{c}0.009 \\
(0.012)\end{array}$ & $\begin{array}{c}0.008 \\
(0.006)\end{array}$ \\
\hline Tax cut unanticipated & $\begin{array}{l}-0.017 \\
(0.017)\end{array}$ & $\begin{array}{l}-0.003 \\
(0.008)\end{array}$ & $\begin{array}{c}0.008 \\
(0.006)\end{array}$ & $\begin{array}{c}0.009 \\
(0.010)\end{array}$ & $\begin{array}{c}0.004 \\
(0.004)\end{array}$ & $\begin{array}{c}0.003 \\
(0.005)\end{array}$ & $\begin{array}{c}0.007 \\
(0.012)\end{array}$ & $\begin{array}{c}-0.011 \\
(0.009)\end{array}$ \\
\hline Male & $\begin{array}{c}-0.017 \\
(0.017)\end{array}$ & $\begin{array}{l}0.017^{\star \star} \\
(0.007)\end{array}$ & $\begin{array}{c}0.003 \\
(0.004)\end{array}$ & $\begin{array}{l}-0.000 \\
(0.008)\end{array}$ & $\begin{array}{l}-0.002 \\
(0.003)\end{array}$ & $\begin{array}{l}-0.009^{*} \\
(0.005)\end{array}$ & $\begin{array}{c}-0.045^{* * *} \\
(0.013)\end{array}$ & $\begin{array}{c}0.009 \\
(0.010)\end{array}$ \\
\hline Household size & $\begin{array}{c}0.008 \\
(0.008)\end{array}$ & $\begin{array}{l}-0.001 \\
(0.003)\end{array}$ & $\begin{array}{c}0.001 \\
(0.002)\end{array}$ & $\begin{array}{c}0.003 \\
(0.004)\end{array}$ & $\begin{array}{l}0.004^{* *} \\
(0.002)\end{array}$ & $\begin{array}{l}-0.001 \\
(0.002)\end{array}$ & $\begin{array}{c}0.003 \\
(0.006)\end{array}$ & $\begin{array}{l}-0.003 \\
(0.004)\end{array}$ \\
\hline Married & $\begin{array}{c}0.027 \\
(0.020)\end{array}$ & $\begin{array}{c}0.001 \\
(0.008)\end{array}$ & $\begin{array}{c}0.000 \\
(0.006)\end{array}$ & $\begin{array}{c}0.007 \\
(0.009)\end{array}$ & $\begin{array}{l}0.005^{\star \star} \\
(0.003)\end{array}$ & $\begin{array}{c}0.002 \\
(0.007)\end{array}$ & $\begin{array}{c}-0.003 \\
(0.014)\end{array}$ & $\begin{array}{c}0.001 \\
(0.010)\end{array}$ \\
\hline Age & $\begin{array}{c}0.003 \\
(0.003)\end{array}$ & $\begin{array}{c}0.002 \\
(0.001)\end{array}$ & $\begin{array}{c}0.002^{* * *} \\
(0.001)\end{array}$ & $\begin{array}{c}0.001 \\
(0.001)\end{array}$ & $\begin{array}{l}-0.000 \\
(0.001)\end{array}$ & $\begin{array}{l}-0.000 \\
(0.001)\end{array}$ & $\begin{array}{c}0.007^{* * *} \\
(0.002)\end{array}$ & $\begin{array}{l}-0.002 \\
(0.002)\end{array}$ \\
\hline $\mathrm{Age}^{2}$ & $\begin{array}{l}-0.000 \\
(0.000)\end{array}$ & $\begin{array}{l}-0.000 \\
(0.000)\end{array}$ & $\begin{array}{c}-0.000^{* *} \\
(0.000)\end{array}$ & $\begin{array}{c}0.000 \\
(0.000)\end{array}$ & $\begin{array}{c}0.000 \\
(0.000)\end{array}$ & $\begin{array}{c}0.000 \\
(0.000)\end{array}$ & $\begin{array}{c}-0.000^{\star *} \\
(0.000)\end{array}$ & $\begin{array}{c}0.000 \\
(0.000)\end{array}$ \\
\hline College & $\begin{array}{c}0.010 \\
(0.014)\end{array}$ & $\begin{array}{l}-0.004 \\
(0.006)\end{array}$ & $\begin{array}{c}0.000 \\
(0.004)\end{array}$ & $\begin{array}{c}0.007 \\
(0.008)\end{array}$ & $\begin{array}{c}0.005 \\
(0.003)\end{array}$ & $\begin{array}{c}0.004 \\
(0.005)\end{array}$ & $\begin{array}{c}-0.026^{\star *} \\
(0.011)\end{array}$ & $\begin{array}{c}-0.013 \\
(0.008)\end{array}$ \\
\hline Retired & $\begin{array}{l}-0.007 \\
(0.032)\end{array}$ & $\begin{array}{c}0.020 \\
(0.014)\end{array}$ & $\begin{array}{l}-0.005 \\
(0.007)\end{array}$ & $\begin{array}{l}-0.011 \\
(0.015)\end{array}$ & $\begin{array}{l}-0.007 \\
(0.005)\end{array}$ & $\begin{array}{c}0.007 \\
(0.011)\end{array}$ & $\begin{array}{c}0.003 \\
(0.024)\end{array}$ & $\begin{array}{c}0.049^{* \star *} \\
(0.017)\end{array}$ \\
\hline Self-employed & $\begin{array}{c}0.005 \\
(0.029)\end{array}$ & $\begin{array}{l}-0.006 \\
(0.011)\end{array}$ & $\begin{array}{l}-0.010 \\
(0.007)\end{array}$ & $\begin{array}{l}-0.005 \\
(0.013)\end{array}$ & $\begin{array}{l}-0.001 \\
(0.006)\end{array}$ & $\begin{array}{l}-0.010^{*} \\
(0.005)\end{array}$ & $\begin{array}{c}0.036 \\
(0.026)\end{array}$ & $\begin{array}{c}0.001 \\
(0.015)\end{array}$ \\
\hline Unemployed & $\begin{array}{c}-0.114^{\star *} \\
(0.051)\end{array}$ & $\begin{array}{c}0.009 \\
(0.025)\end{array}$ & $\begin{array}{l}-0.002 \\
(0.015)\end{array}$ & $\begin{array}{c}0.031 \\
(0.044)\end{array}$ & $\begin{array}{c}-0.011^{* * *} \\
(0.003)\end{array}$ & $\begin{array}{c}0.018 \\
(0.027)\end{array}$ & $\begin{array}{l}-0.040 \\
(0.033)\end{array}$ & $\begin{array}{c}-0.027^{* *} \\
(0.014)\end{array}$ \\
\hline Homeowner & $\begin{array}{c}0.014 \\
(0.016)\end{array}$ & $\begin{array}{l}-0.002 \\
(0.007)\end{array}$ & $\begin{array}{c}0.005 \\
(0.005)\end{array}$ & $\begin{array}{l}0.018^{* *} \\
(0.008)\end{array}$ & $\begin{array}{l}-0.002 \\
(0.003)\end{array}$ & $\begin{array}{c}0.007 \\
(0.005)\end{array}$ & $\begin{array}{l}-0.015 \\
(0.012)\end{array}$ & $\begin{array}{c}0.005 \\
(0.009)\end{array}$ \\
\hline Financial literacy score & $\begin{array}{l}0.020^{\star} \\
(0.011)\end{array}$ & $\begin{array}{l}-0.007 \\
(0.006)\end{array}$ & $\begin{array}{c}0.002 \\
(0.002)\end{array}$ & $\begin{array}{c}0.005 \\
(0.005)\end{array}$ & $\begin{array}{c}0.000 \\
(0.002)\end{array}$ & $\begin{array}{c}0.002 \\
(0.003)\end{array}$ & $\begin{array}{l}-0.003 \\
(0.008)\end{array}$ & $\begin{array}{l}-0.014^{*} \\
(0.008)\end{array}$ \\
\hline Risk tolerance & $\begin{array}{l}-0.003 \\
(0.005)\end{array}$ & $\begin{array}{l}-0.003 \\
(0.002)\end{array}$ & $\begin{array}{c}0.001 \\
(0.001)\end{array}$ & $\begin{array}{l}-0.005^{\star} \\
(0.003)\end{array}$ & $\begin{array}{l}-0.001 \\
(0.001)\end{array}$ & $\begin{array}{c}0.002 \\
(0.002)\end{array}$ & $\begin{array}{c}0.014^{\star \star \star} \\
(0.004)\end{array}$ & $\begin{array}{c}-0.008^{* \star *} \\
(0.003)\end{array}$ \\
\hline Patience & $\begin{array}{c}0.003 \\
(0.005)\end{array}$ & $\begin{array}{l}-0.001 \\
(0.002)\end{array}$ & $\begin{array}{l}-0.000 \\
(0.001)\end{array}$ & $\begin{array}{c}0.002 \\
(0.002)\end{array}$ & $\begin{array}{c}0.001 \\
(0.001)\end{array}$ & $\begin{array}{c}0.001 \\
(0.001)\end{array}$ & $\begin{array}{c}0.001 \\
(0.003)\end{array}$ & $\begin{array}{l}-0.005^{\star} \\
(0.003)\end{array}$ \\
\hline Impulsive buying & $\begin{array}{l}0.012^{* \star} \\
(0.006)\end{array}$ & $\begin{array}{c}0.001 \\
(0.003)\end{array}$ & $\begin{array}{l}0.003^{*} \\
(0.001)\end{array}$ & $\begin{array}{c}0.003 \\
(0.002)\end{array}$ & $\begin{array}{l}-0.002^{* *} \\
(0.001)\end{array}$ & $\begin{array}{l}-0.002 \\
(0.002)\end{array}$ & $\begin{array}{c}0.003 \\
(0.004)\end{array}$ & $\begin{array}{l}-0.003 \\
(0.003)\end{array}$ \\
\hline Self-control & $\begin{array}{l}-0.009^{\star} \\
(0.005)\end{array}$ & $\begin{array}{l}-0.003 \\
(0.002)\end{array}$ & $\begin{array}{c}0.000 \\
(0.001)\end{array}$ & $\begin{array}{c}0.000 \\
(0.002)\end{array}$ & $\begin{array}{l}-0.001 \\
(0.001)\end{array}$ & $\begin{array}{c}0.000 \\
(0.001)\end{array}$ & $\begin{array}{c}-0.020^{* * *} \\
(0.004)\end{array}$ & $\begin{array}{l}-0.005 \\
(0.003)\end{array}$ \\
\hline Rainy day savings - none & $\begin{array}{c}0.018 \\
(0.019)\end{array}$ & $\begin{array}{l}-0.002 \\
(0.009)\end{array}$ & $\begin{array}{c}0.009 \\
(0.007)\end{array}$ & $\begin{array}{c}0.004 \\
(0.009)\end{array}$ & $\begin{array}{c}0.001 \\
(0.004)\end{array}$ & $\begin{array}{l}-0.000 \\
(0.005)\end{array}$ & $\begin{array}{c}-0.033^{* * *} \\
(0.012)\end{array}$ & $\begin{array}{c}0.009 \\
(0.012)\end{array}$ \\
\hline Rainy day savings - na & $\begin{array}{l}-0.020 \\
(0.025)\end{array}$ & $\begin{array}{l}0.050^{\star \star} \\
(0.025)\end{array}$ & $\begin{array}{c}0.011 \\
(0.012)\end{array}$ & $\begin{array}{c}-0.028^{* * *} \\
(0.007)\end{array}$ & $\begin{array}{l}-0.007 \\
(0.004)\end{array}$ & $\begin{array}{c}0.015 \\
(0.015)\end{array}$ & $\begin{array}{l}-0.015 \\
(0.021)\end{array}$ & $\begin{array}{l}-0.001 \\
(0.021)\end{array}$ \\
\hline Constant & $\begin{array}{l}0.555^{\star *} \\
(0.247)\end{array}$ & $\begin{array}{c}0.091 \\
(0.100)\end{array}$ & $\begin{array}{l}-0.050 \\
(0.067)\end{array}$ & $\begin{array}{l}0.187^{* *} \\
(0.090)\end{array}$ & $\begin{array}{c}0.073 \\
(0.050)\end{array}$ & $\begin{array}{c}0.097 \\
(0.079)\end{array}$ & $\begin{array}{c}0.031 \\
(0.208)\end{array}$ & $\begin{array}{l}0.225^{\star *} \\
(0.114)\end{array}$ \\
\hline $\begin{array}{l}\text { Observations } \\
\mathrm{R}^{2}\end{array}$ & $\begin{array}{l}1,514 \\
0.121\end{array}$ & $\begin{array}{l}1,514 \\
0.023\end{array}$ & $\begin{array}{l}1,514 \\
0.035\end{array}$ & $\begin{array}{l}1,514 \\
0.026\end{array}$ & $\begin{array}{l}1,514 \\
0.018\end{array}$ & $\begin{array}{l}1,514 \\
0.025\end{array}$ & $\begin{array}{l}1,514 \\
0.055\end{array}$ & $\begin{array}{l}1,514 \\
0.046\end{array}$ \\
\hline
\end{tabular}


Table 6: Regression Analyses: Use of tax rebate (Saving product-categories)

\begin{tabular}{|c|c|c|c|c|c|c|c|c|}
\hline Sample Statistics & $\begin{array}{c}\begin{array}{c}\text { Risky } \\
\text { assets }\end{array} \\
(1)\end{array}$ & $\begin{array}{c}\begin{array}{c}\text { Risky } \\
\text { assets } \\
\text { (plan) }\end{array} \\
(2)\end{array}$ & $\begin{array}{c}\begin{array}{c}\text { Robo } \\
\text { advisor }\end{array} \\
(3)\end{array}$ & $\begin{array}{c}\begin{array}{c}\text { Pension } \\
\text { Insurance }\end{array} \\
(4)\end{array}$ & $\begin{array}{c}\begin{array}{c}\text { Riester/ } \\
\text { Rürup }\end{array} \\
\text { (5) }\end{array}$ & $\begin{array}{c}\text { Savings } \\
\text { Account } \\
(6)\end{array}$ & $\frac{\text { Cash }}{(7)}$ & $\frac{\text { Other }}{(8)}$ \\
\hline Treat: Yearly & $\begin{array}{c}0.051^{* * *} \\
(0.014)\end{array}$ & $\begin{array}{l}-0.029^{*} \\
(0.015)\end{array}$ & $\begin{array}{c}0.003 \\
(0.004)\end{array}$ & $\begin{array}{c}0.001 \\
(0.005)\end{array}$ & $\begin{array}{l}-0.004 \\
(0.003)\end{array}$ & $\begin{array}{c}0.005 \\
(0.015)\end{array}$ & $\begin{array}{l}0.019^{*} \\
(0.010)\end{array}$ & $\begin{array}{l}-0.008 \\
(0.009)\end{array}$ \\
\hline Treat: $10-$ Yearly & $\begin{array}{c}0.050^{\star * *} \\
(0.014)\end{array}$ & $\begin{array}{l}-0.008 \\
(0.015)\end{array}$ & $\begin{array}{c}0.002 \\
(0.003)\end{array}$ & $\begin{array}{c}0.003 \\
(0.005)\end{array}$ & $\begin{array}{c}0.005 \\
(0.004)\end{array}$ & $\begin{array}{l}-0.013 \\
(0.014)\end{array}$ & $\begin{array}{l}-0.004 \\
(0.009)\end{array}$ & $\begin{array}{l}-0.008 \\
(0.009)\end{array}$ \\
\hline Taxable income (log) & $\begin{array}{l}0.066^{* *} \\
(0.028)\end{array}$ & $\begin{array}{l}0.041^{*} \\
(0.025)\end{array}$ & $\begin{array}{c}0.009 \\
(0.007)\end{array}$ & $\begin{array}{c}0.020 \\
(0.013)\end{array}$ & $\begin{array}{l}-0.004 \\
(0.003)\end{array}$ & $\begin{array}{c}-0.064^{* * *} \\
(0.017)\end{array}$ & $\begin{array}{c}0.003 \\
(0.013)\end{array}$ & $\begin{array}{c}0.003 \\
(0.014)\end{array}$ \\
\hline Income increase (log) & $\begin{array}{l}-0.008 \\
(0.013)\end{array}$ & $\begin{array}{l}-0.004 \\
(0.013)\end{array}$ & $\begin{array}{l}-0.003 \\
(0.003)\end{array}$ & $\begin{array}{l}-0.006 \\
(0.006)\end{array}$ & $\begin{array}{c}0.004^{* * *} \\
(0.001)\end{array}$ & $\begin{array}{c}0.033^{* * *} \\
(0.008)\end{array}$ & $\begin{array}{c}0.005 \\
(0.007)\end{array}$ & $\begin{array}{l}-0.001 \\
(0.007)\end{array}$ \\
\hline Tax cut unanticipated & $\begin{array}{l}-0.004 \\
(0.014)\end{array}$ & $\begin{array}{l}-0.012 \\
(0.014)\end{array}$ & $\begin{array}{l}-0.002 \\
(0.003)\end{array}$ & $\begin{array}{l}-0.007 \\
(0.004)\end{array}$ & $\begin{array}{l}-0.002 \\
(0.003)\end{array}$ & $\begin{array}{c}0.008 \\
(0.015)\end{array}$ & $\begin{array}{c}0.004 \\
(0.010)\end{array}$ & $\begin{array}{l}-0.004 \\
(0.009)\end{array}$ \\
\hline Male & $\begin{array}{c}0.019 \\
(0.012)\end{array}$ & $\begin{array}{c}0.001 \\
(0.013)\end{array}$ & $\begin{array}{l}-0.001 \\
(0.004)\end{array}$ & $\begin{array}{l}-0.004 \\
(0.004)\end{array}$ & $\begin{array}{c}0.004 \\
(0.003)\end{array}$ & $\begin{array}{c}0.001 \\
(0.014)\end{array}$ & $\begin{array}{c}0.005 \\
(0.009)\end{array}$ & $\begin{array}{c}0.010 \\
(0.009)\end{array}$ \\
\hline Household size & $\begin{array}{l}-0.011 \\
(0.007)\end{array}$ & $\begin{array}{c}-0.018^{* * *} \\
(0.007)\end{array}$ & $\begin{array}{c}0.000 \\
(0.002)\end{array}$ & $\begin{array}{l}-0.004 \\
(0.003)\end{array}$ & $\begin{array}{c}0.002 \\
(0.002)\end{array}$ & $\begin{array}{c}0.006 \\
(0.007)\end{array}$ & $\begin{array}{l}-0.003 \\
(0.004)\end{array}$ & $\begin{array}{l}-0.001 \\
(0.004)\end{array}$ \\
\hline Married & $\begin{array}{c}-0.047^{* * *} \\
(0.018)\end{array}$ & $\begin{array}{l}-0.016 \\
(0.016)\end{array}$ & $\begin{array}{l}-0.007 \\
(0.004)\end{array}$ & $\begin{array}{l}-0.006 \\
(0.008)\end{array}$ & $\begin{array}{c}0.000 \\
(0.004)\end{array}$ & $\begin{array}{l}0.026^{*} \\
(0.015)\end{array}$ & $\begin{array}{l}-0.007 \\
(0.011)\end{array}$ & $\begin{array}{l}-0.006 \\
(0.010)\end{array}$ \\
\hline Age & $\begin{array}{l}-0.004 \\
(0.003)\end{array}$ & $\begin{array}{c}-0.007^{* *} \\
(0.003)\end{array}$ & $\begin{array}{l}-0.000 \\
(0.000)\end{array}$ & $\begin{array}{c}0.000 \\
(0.001)\end{array}$ & $\begin{array}{c}0.000 \\
(0.001)\end{array}$ & $\begin{array}{l}-0.001 \\
(0.002)\end{array}$ & $\begin{array}{l}-0.000 \\
(0.002)\end{array}$ & $\begin{array}{l}-0.000 \\
(0.002)\end{array}$ \\
\hline $\mathrm{Age}^{2}$ & $\begin{array}{c}0.000 \\
(0.000)\end{array}$ & $\begin{array}{l}0.000^{*} \\
(0.000)\end{array}$ & $\begin{array}{c}0.000 \\
(0.000)\end{array}$ & $\begin{array}{l}-0.000 \\
(0.000)\end{array}$ & $\begin{array}{l}-0.000 \\
(0.000)\end{array}$ & $\begin{array}{l}-0.000 \\
(0.000)\end{array}$ & $\begin{array}{c}0.000 \\
(0.000)\end{array}$ & $\begin{array}{l}-0.000 \\
(0.000)\end{array}$ \\
\hline College & $\begin{array}{c}0.031^{* * *} \\
(0.012)\end{array}$ & $\begin{array}{l}-0.009 \\
(0.013)\end{array}$ & $\begin{array}{l}-0.002 \\
(0.004)\end{array}$ & $\begin{array}{c}0.000 \\
(0.005)\end{array}$ & $\begin{array}{c}0.004 \\
(0.003)\end{array}$ & $\begin{array}{l}-0.008 \\
(0.012)\end{array}$ & $\begin{array}{l}-0.001 \\
(0.007)\end{array}$ & $\begin{array}{c}-0.015^{\star *} \\
(0.007)\end{array}$ \\
\hline Retired & $\begin{array}{l}-0.020 \\
(0.024)\end{array}$ & $\begin{array}{l}-0.032 \\
(0.019)\end{array}$ & $\begin{array}{l}-0.002 \\
(0.005)\end{array}$ & $\begin{array}{l}-0.003 \\
(0.003)\end{array}$ & $\begin{array}{l}-0.000 \\
(0.003)\end{array}$ & $\begin{array}{l}-0.004 \\
(0.022)\end{array}$ & $\begin{array}{c}0.001 \\
(0.015)\end{array}$ & $\begin{array}{l}-0.001 \\
(0.012)\end{array}$ \\
\hline Self-employed & $\begin{array}{l}-0.009 \\
(0.025)\end{array}$ & $\begin{array}{c}0.001 \\
(0.028)\end{array}$ & $\begin{array}{l}-0.002 \\
(0.006)\end{array}$ & $\begin{array}{l}-0.001 \\
(0.012)\end{array}$ & $\begin{array}{c}0.021 \\
(0.014)\end{array}$ & $\begin{array}{c}-0.043^{* *} \\
(0.018)\end{array}$ & $\begin{array}{c}0.007 \\
(0.019)\end{array}$ & $\begin{array}{c}0.009 \\
(0.020)\end{array}$ \\
\hline Unemployed & $\begin{array}{c}0.046 \\
(0.046)\end{array}$ & $\begin{array}{l}-0.003 \\
(0.033)\end{array}$ & $\begin{array}{l}-0.003 \\
(0.004)\end{array}$ & $\begin{array}{c}0.056 \\
(0.041)\end{array}$ & $\begin{array}{l}-0.001 \\
(0.004)\end{array}$ & $\begin{array}{l}-0.004 \\
(0.044)\end{array}$ & $\begin{array}{l}-0.009 \\
(0.025)\end{array}$ & $\begin{array}{c}0.023 \\
(0.039)\end{array}$ \\
\hline Homeowner & $\begin{array}{l}-0.019 \\
(0.014)\end{array}$ & $\begin{array}{l}-0.002 \\
(0.014)\end{array}$ & $\begin{array}{c}0.002 \\
(0.003)\end{array}$ & $\begin{array}{l}-0.006 \\
(0.005)\end{array}$ & $\begin{array}{l}-0.008^{\star *} \\
(0.004)\end{array}$ & $\begin{array}{l}-0.026^{\star} \\
(0.014)\end{array}$ & $\begin{array}{l}-0.005 \\
(0.009)\end{array}$ & $\begin{array}{c}0.005 \\
(0.008)\end{array}$ \\
\hline Financial literacy score & $\begin{array}{c}0.005 \\
(0.007)\end{array}$ & $\begin{array}{l}0.017^{\star *} \\
(0.008)\end{array}$ & $\begin{array}{c}0.001 \\
(0.001)\end{array}$ & $\begin{array}{c}0.002 \\
(0.003)\end{array}$ & $\begin{array}{l}-0.002 \\
(0.002)\end{array}$ & $\begin{array}{l}-0.001 \\
(0.009)\end{array}$ & $\begin{array}{l}-0.006 \\
(0.007)\end{array}$ & $\begin{array}{l}-0.003 \\
(0.006)\end{array}$ \\
\hline Risk tolerance & $\begin{array}{c}0.029^{* * *} \\
(0.004)\end{array}$ & $\begin{array}{c}0.023^{\star * *} \\
(0.004)\end{array}$ & $\begin{array}{c}0.001 \\
(0.001)\end{array}$ & $\begin{array}{l}-0.002 \\
(0.001)\end{array}$ & $\begin{array}{l}-0.000 \\
(0.001)\end{array}$ & $\begin{array}{c}-0.031^{* * *} \\
(0.004)\end{array}$ & $\begin{array}{l}-0.005 \\
(0.003)\end{array}$ & $\begin{array}{l}-0.003 \\
(0.003)\end{array}$ \\
\hline Patience & $\begin{array}{c}0.002 \\
(0.004)\end{array}$ & $\begin{array}{c}0.006 \\
(0.004)\end{array}$ & $\begin{array}{l}-0.001 \\
(0.001)\end{array}$ & $\begin{array}{l}0.002^{*} \\
(0.001)\end{array}$ & $\begin{array}{l}-0.000 \\
(0.001)\end{array}$ & $\begin{array}{l}-0.006 \\
(0.004)\end{array}$ & $\begin{array}{l}-0.002 \\
(0.003)\end{array}$ & $\begin{array}{l}-0.001 \\
(0.002)\end{array}$ \\
\hline Impulsive buying & $\begin{array}{c}-0.011^{* * *} \\
(0.004)\end{array}$ & $\begin{array}{c}0.001 \\
(0.004)\end{array}$ & $\begin{array}{l}-0.000 \\
(0.001)\end{array}$ & $\begin{array}{l}-0.001 \\
(0.002)\end{array}$ & $\begin{array}{c}0.002 \\
(0.001)\end{array}$ & $\begin{array}{c}-0.012^{* * *} \\
(0.004)\end{array}$ & $\begin{array}{c}-0.008^{\star * *} \\
(0.003)\end{array}$ & $\begin{array}{c}-0.005^{\star *} \\
(0.002)\end{array}$ \\
\hline Self-control & $\begin{array}{l}0.008^{*} \\
(0.004)\end{array}$ & $\begin{array}{l}0.013^{\star * *} \\
(0.004)\end{array}$ & $\begin{array}{c}0.001 \\
(0.001)\end{array}$ & $\begin{array}{c}0.001 \\
(0.001)\end{array}$ & $\begin{array}{l}0.002^{\star \star} \\
(0.001)\end{array}$ & $\begin{array}{c}0.000 \\
(0.005)\end{array}$ & $\begin{array}{c}0.002 \\
(0.003)\end{array}$ & $\begin{array}{l}0.005^{*} \\
(0.002)\end{array}$ \\
\hline Rainy day savings - none & $\begin{array}{l}-0.017 \\
(0.013)\end{array}$ & $\begin{array}{l}-0.019 \\
(0.014)\end{array}$ & $\begin{array}{c}0.001 \\
(0.003)\end{array}$ & $\begin{array}{l}0.016^{\star \star} \\
(0.008)\end{array}$ & $\begin{array}{c}-0.006^{\star *} \\
(0.003)\end{array}$ & $\begin{array}{c}-0.048^{\star \star *} \\
(0.015)\end{array}$ & $\begin{array}{c}0.011 \\
(0.011)\end{array}$ & $\begin{array}{c}0.001 \\
(0.010)\end{array}$ \\
\hline Rainy day savings - na & $\begin{array}{c}-0.038^{\star \star} \\
(0.019)\end{array}$ & $\begin{array}{l}0.028 \\
(0.031)\end{array}$ & $\begin{array}{c}0.001 \\
(0.008)\end{array}$ & $\begin{array}{c}0.005 \\
(0.016)\end{array}$ & $\begin{array}{l}-0.006 \\
(0.005)\end{array}$ & $\begin{array}{c}0.007 \\
(0.034)\end{array}$ & $\begin{array}{c}0.014 \\
(0.024)\end{array}$ & $\begin{array}{l}-0.002 \\
(0.018)\end{array}$ \\
\hline Constant & $\begin{array}{c}-0.660^{\star \star *} \\
(0.256)\end{array}$ & $\begin{array}{l}-0.278 \\
(0.236)\end{array}$ & $\begin{array}{l}-0.071 \\
(0.065)\end{array}$ & $\begin{array}{l}-0.173 \\
(0.116)\end{array}$ & $\begin{array}{c}0.021 \\
(0.031)\end{array}$ & $\begin{array}{c}0.925^{\star \star \star} \\
(0.182)\end{array}$ & $\begin{array}{c}0.066 \\
(0.123)\end{array}$ & $\begin{array}{c}0.053 \\
(0.133)\end{array}$ \\
\hline $\begin{array}{l}\text { Observations } \\
\mathrm{R}^{2}\end{array}$ & $\begin{array}{l}1,521 \\
0.102\end{array}$ & $\begin{array}{l}1,521 \\
0.078\end{array}$ & $\begin{array}{l}1,521 \\
0.008\end{array}$ & $\begin{array}{l}1,521 \\
0.035\end{array}$ & $\begin{array}{l}1,521 \\
0.024\end{array}$ & $\begin{array}{l}1,521 \\
0.083\end{array}$ & $\begin{array}{l}1,521 \\
0.017\end{array}$ & $\begin{array}{l}1,521 \\
0.013\end{array}$ \\
\hline
\end{tabular}




\section{Figures}

Figure 1: Solidary surcharge as function of taxable income

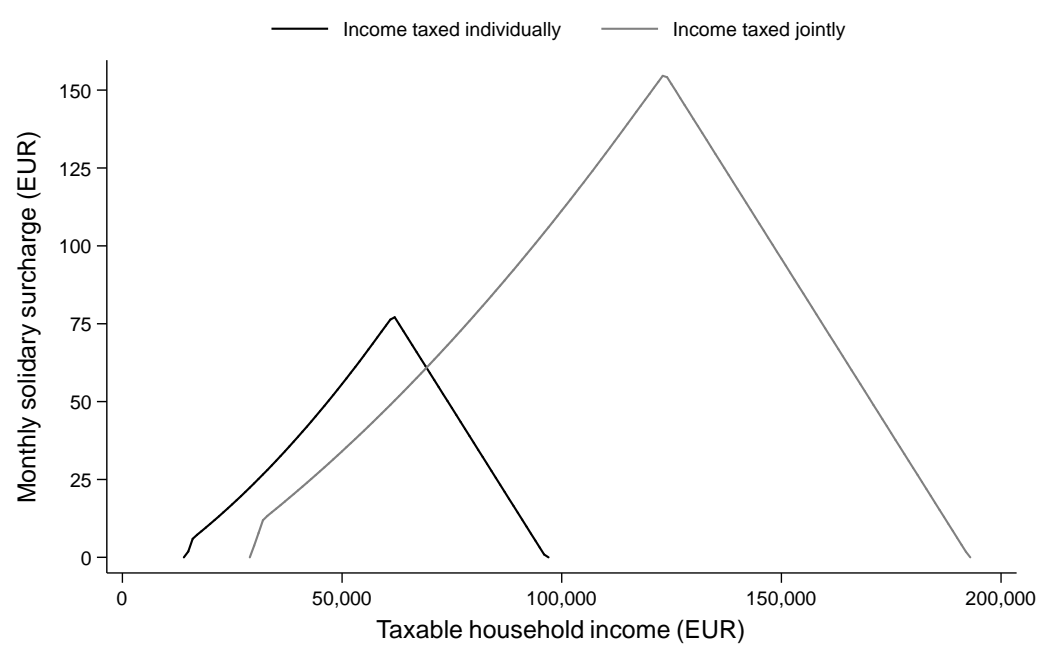


Figure 2: Taxable income distribution among households
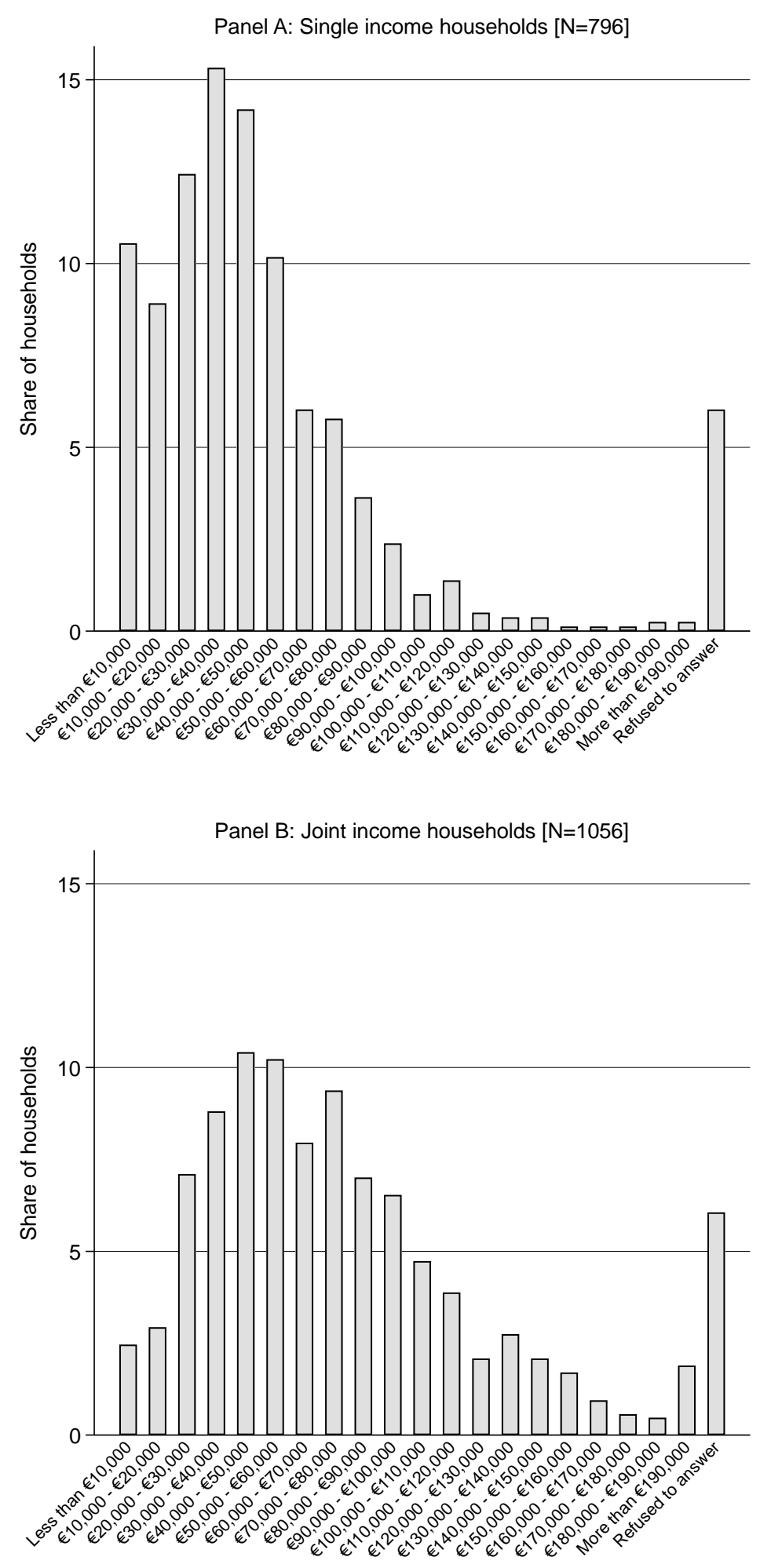
Figure 3: Distribution of monthly tax increase
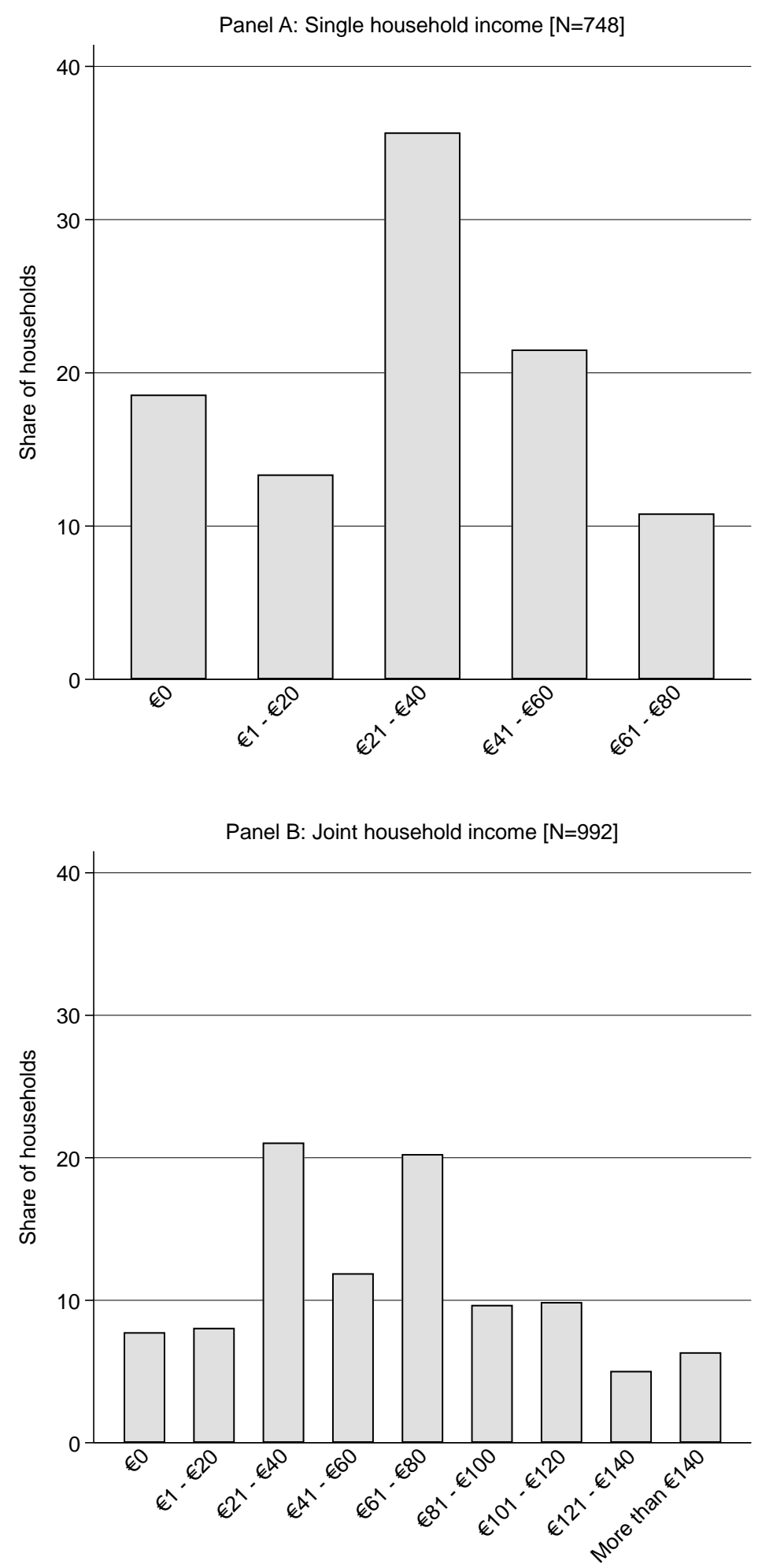
Figure 4: Histogram of the income increase allocation distribution
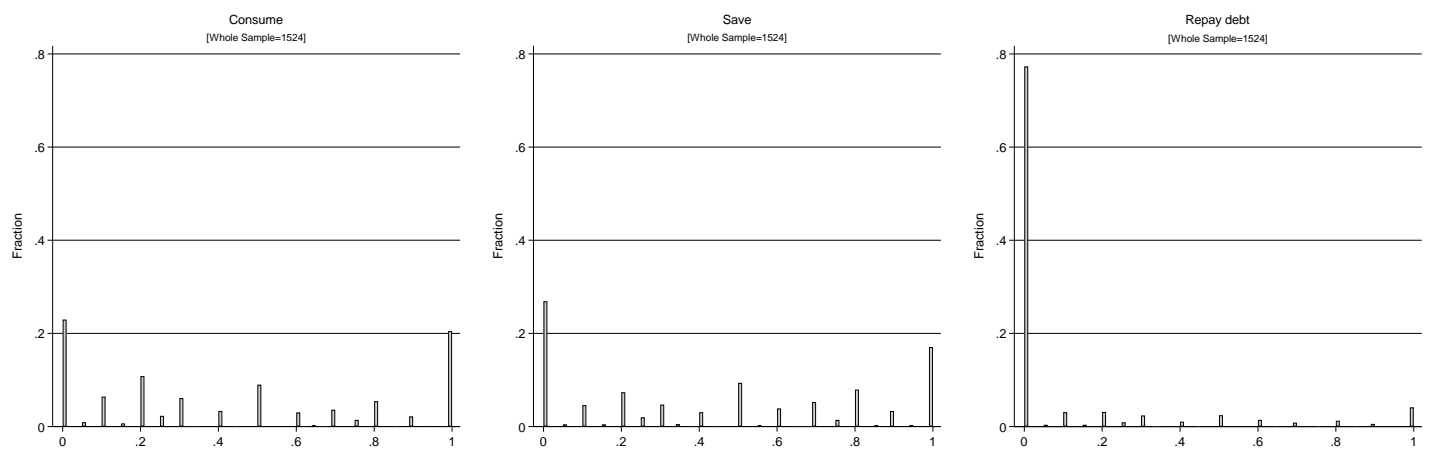


\section{Appendix}

Appendix 1: Description of explanatory variables

\begin{tabular}{|c|c|c|}
\hline Name & Survey & Description \\
\hline Age & Entry & Describes the respondent's age in years. \\
\hline Male & Entry & Dummy variable that equals one if the respondent is male; zero for female. \\
\hline Married & Entry & Dummy variable that equals one if the respondent's income is taxed jointly; zero otherwise. \\
\hline Household size & Entry & Describes the number of persons living in the respondent's household. \\
\hline Taxable income & Nov20 & Describes the household's self-reported taxable income in steps of EUR 10,000. \\
\hline $\begin{array}{l}\text { Taxable income taxed } \\
\text { jointly }\end{array}$ & Nov20 & $\begin{array}{l}\text { Dummy variable that equals one if the taxable income is taxed jointly with a marital partner; } \\
\text { zero otherwise. }\end{array}$ \\
\hline Income increase & Nov20 & $\begin{array}{l}\text { Describes the household's monthly tax increase calculated from the Households reported } \\
\text { taxable income and whether it was taxed jointly with a marital partner. }\end{array}$ \\
\hline Tax cut unanticipated & Nov20 & $\begin{array}{l}\text { Dummy variable that equals one if a respondent indicated that he/she did not know if the } \\
\text { upcoming abandonment of the solidary surcharge; zero otherwise. }\end{array}$ \\
\hline College & Entry & $\begin{array}{l}\text { Dummy variable that equals one if a respondent has obtained a college degree or a higher } \\
\text { qualification; zero otherwise. }\end{array}$ \\
\hline Retired & Entry & Dummy variable that equals one if a respondent is retired; zero otherwise. \\
\hline Self-employed & Entry & Dummy variable that equals one if a respondent is self-employed; zero otherwise. \\
\hline Unemployed & Entry & Dummy variable that equals one if a respondent is unemployed; zero otherwise. \\
\hline Homeowner & Entry & Dummy variable that equals one if a respondent owns a house; zero otherwise. \\
\hline Financial literacy score & Entry & $\begin{array}{l}\text { Ordinal variable that measures the respondents' correctly answered Financial literacy } \\
\text { question }\{0-3\} \text {; We use the three financial literacy questions by Lusardi and Mitchell (2008).. }\end{array}$ \\
\hline Risk tolerance & Entry & $\begin{array}{l}\text { Ordinal variable that measures the respondents' propensity to take financial risks }\{1-7\} \text {. } \\
\text { Corresponding question from the survey: "How would you rate your personal willingness to } \\
\text { take risks when taking savings or investment decisions?" } 1=\text { "not willing to take any risks", } \\
7=\text { "very willing to take risks"; }\end{array}$ \\
\hline Patience & Nov20 & $\begin{array}{l}\text { Ordinal variable that measures the respondents' self-assessed patience }\{1-7\} \text {. } \\
\text { Corresponding question from the survey: "To what extent do you agree with the following } \\
\text { statements? In general, I am a patient person." } 1=\text { "do not agree at all", } 7=\text { "fully agree" }\end{array}$ \\
\hline $\begin{array}{l}\text { Rainy day savings } \\
\text { - none }\end{array}$ & Entry & $\begin{array}{l}\text { Dummy variable that equals one if a respondent has no rainy day savings; zero otherwise. } \\
\text { Corresponding survey question: "Have you put aside enough money to cope with a potential } \\
\text { emergency that would leave you } 3 \text { months without an income?" } 1=\text { "Yes" } 2=\text { "No" } 3=\text { "No } \\
\text { answer" }\end{array}$ \\
\hline $\begin{array}{l}\text { Rainy day savings } \\
\text { - na }\end{array}$ & Entry & $\begin{array}{l}\text { Dummy variable that equals one if a respondent refused to answer the question on rainy } \\
\text { day savings; zero otherwise. Corresponding survey question: "Have you put aside enough } \\
\text { money to cope with a potential emergency that would leave you } 3 \text { months without an } \\
\text { income?" } 1=\text { "Yes" } 2 \text { = "No" } 3 \text { = "No answer" }\end{array}$ \\
\hline Impulsive buying & Nov20 & $\begin{array}{l}\text { Ordinal variable that measures the respondents' self-assessed tendency towards impulsive } \\
\text { buying }\{1-7\} \text {. Corresponding question from the survey: "To what extent do you agree with } \\
\text { the following statements? I am impulsive and tend to buy things even when I can't really } \\
\text { afford them." } 1 \text { = "do not agree at all", } 7 \text { = "fully agree" }\end{array}$ \\
\hline Self-control & Nov20 & $\begin{array}{l}\text { Ordinal variable that measures the respondents' self-assessed self-control }\{1-7\} \text {. } \\
\text { Corresponding question from the survey: "To what extent do you agree with the following } \\
\text { statements? I am willing to forego something today in order to benefit more from it in the } \\
\text { future." } 1 \text { = "do not agree at all", } 7 \text { = "fully agree" }\end{array}$ \\
\hline Treat: Monthly & Nov20 & $\begin{array}{l}\text { Dummy variable that indicates the respondent's allocation to the monthly treatment group; } \\
\text { zero otherwise. }\end{array}$ \\
\hline Treat: Yearly & Nov20 & $\begin{array}{l}\text { Dummy variable that indicates the respondent's allocation to the yearly treatment group; } \\
\text { zero otherwise. }\end{array}$ \\
\hline Treat: 10 -yearly & Nov20 & $\begin{array}{l}\text { Dummy variable that indicates the respondent's allocation to the } 10 \text {-yearly treatment group; } \\
\text { zero otherwise. }\end{array}$ \\
\hline
\end{tabular}


Appendix 2: Definition of dependent variables

\begin{tabular}{|c|c|}
\hline Name & Description \\
\hline $\begin{array}{l}\text { Qualitative MPC } \\
\text { question }\end{array}$ & $\begin{array}{l}\text { Set of dummy variables that equal } 1 \text { if the respondent intends to use the income increase mostly for spending, saving, } \\
\text { or repaying debt, respectively; zero otherwise. See section } 2.4 \text { for the exact wording of the corresponding survey } \\
\text { question. }\end{array}$ \\
\hline Saving (qual.) & $\begin{array}{l}\text { Dummy variable that equals } 1 \text { if the respondent answers the quantitative MPC questions with "I will mostly save the } \\
\text { income increase"; zero otherwise. Derived from the qualitative MPC question. }\end{array}$ \\
\hline Spending (qual.) & $\begin{array}{l}\text { Dummy variable that equals } 1 \text { if the respondent answers the quantitative MPC questions with "I will mostly spend the } \\
\text { income increase"; zero otherwise. Derived from the qualitative MPC question. }\end{array}$ \\
\hline Repay debt (qual.) & $\begin{array}{l}\text { Dummy variable that equals } 1 \text { if the respondent answers the quantitative MPC questions with "I will mostly save the } \\
\text { income increase"; zero otherwise. Derived from the qualitative MPC question. }\end{array}$ \\
\hline $\begin{array}{l}\text { Quantitative MPC } \\
\text { question }\end{array}$ & $\begin{array}{l}\text { Set of ordinal variables that indicate the share of the income increase allocated to spending, saving, and repaying } \\
\text { debt, respectively. The minimum value of each category is } 0 \text { and the maximum is } 100 \text {. The sum of all three must not } \\
\text { be larger than } 100 \text {. See section } 2.4 \text { for the exact wording of the survey question. }\end{array}$ \\
\hline Spending (quant.) & Ordinal variable that indicates the allocation of the income increase to "spending" $\{0-100\}$. \\
\hline Saving (quant.) & Ordinal variable that indicates the allocation of the income increase to "saving" $\{0-100\}$ \\
\hline Repay debt (quant.) & Ordinal variable that indicates the allocation of the income increase to "repaying debt" $\{0-100\}$. \\
\hline $\begin{array}{l}\text { Saving allocation } \\
\text { question }\end{array}$ & $\begin{array}{l}\text { Set of Ordinal variables that indicate the respondent's allocation of the income increase to the different saving } \\
\text { categories. The question was only asked if Saving (quant.) }>0 \text {. The minimum value of each category is } 0 \text { and the } \\
\text { maximum is } 100 \text {. The sum of all allocations must not be larger than } 100 \text {. See section } 2.4 \text { for the exact wording of the } \\
\text { corresponding survey question. The Shares were multiplied with 'Saving (quant.)'. }\end{array}$ \\
\hline Risky assets & $\begin{array}{l}\text { Ordinal variable that indicates the allocation of income increase to the saving category "Securities (e.g. stocks or } \\
\text { funds) as a one-off investment" }\{0-100\} \text {. Derived from the saving allocation question. }\end{array}$ \\
\hline Risky assets (plan) & $\begin{array}{l}\text { Ordinal variable that indicates the allocation of the income increase to the saving category "Securities (e.g. stocks } \\
\text { or funds) as a savings plan" }\{0-100\} \text {. Derived from the saving allocation question. }\end{array}$ \\
\hline Robo advisor & $\begin{array}{l}\text { Ordinal variable that indicates the allocation of the income increase to the saving category "Automated asset } \\
\text { management ("Robo-Advisor")" }\{0-100\} \text {. Derived from the saving allocation question. }\end{array}$ \\
\hline Pension Insurance & $\begin{array}{l}\text { Ordinal variable that indicates the allocation of the income increase to the saving category "Pension/ capital life } \\
\text { insurance" }\{0-100\} \text {. Derived from the saving allocation question. }\end{array}$ \\
\hline Riester/ Rürup & $\begin{array}{l}\text { Ordinal variable that indicates the allocation of the income increase to the saving category "Riester/ Rürup pension } \\
\text { plan" }\{0-100\} \text {. Derived from the saving allocation question. }\end{array}$ \\
\hline Savings Account & $\begin{array}{l}\text { Ordinal variable that indicates the allocation of the income increase to the saving category "Savings account/ } \\
\text { bankbook" }\{0-100\} \text {. Derived from the saving allocation question. }\end{array}$ \\
\hline Cash & $\begin{array}{l}\text { Ordinal variable that indicates the allocation of the income increase to the saving category "Cash" }\{0-100\} \text {. Derived } \\
\text { from the saving allocation question. }\end{array}$ \\
\hline Other & $\begin{array}{l}\text { Ordinal variable that indicates the allocation of the income increase to the saving category "Other" }\{0-100\} \text {. Derived } \\
\text { from the saving allocation question. }\end{array}$ \\
\hline $\begin{array}{l}\text { Spending allocation } \\
\text { question }\end{array}$ & $\begin{array}{l}\text { Set of ordinal variables that indicate the allocation of the income increase to different spending categories. The } \\
\text { question was only asked if Spending (quant.) }>0 \text {. The minimum value of each category is } 0 \text { and the maximum is } \\
100 \text {. The sum of all three must not be larger than } 100 \text {. See section } 2.4 \text { for the exact wording of the corresponding } \\
\text { survey question. The Shares were multiplied with 'Spending (quant.)'. }\end{array}$ \\
\hline Cost of living & $\begin{array}{l}\text { Ordinal variable that indicates the allocation of the income increase to the saving category "General cost of living", } \\
\{0-100\} \text {. Derived from the Spending allocation question. }\end{array}$ \\
\hline $\begin{array}{l}\text { Durable goods } \\
\text { > EUR } 1,000\end{array}$ & $\begin{array}{l}\text { Ordinal variable that indicates the allocation of the income increase to the saving category "Larger purchases worth } \\
\text { more than } € 1,000 \text { (e.g. cars, ...)" }\{0-100\} \text {. Derived from the spending allocation question. }\end{array}$ \\
\hline $\begin{array}{l}\text { Durable goods } \\
<\text { EUR } 1,000\end{array}$ & $\begin{array}{l}\text { Ordinal variable that indicates the allocation of the income increase to the saving category "Larger purchases worth } \\
€ 1,000 \text { or less (e.g. Electrical appliances, sports equipment, clothing, ...)" }\{0-100\} \text {. Derived from the spending } \\
\text { allocation question. }\end{array}$ \\
\hline $\begin{array}{l}\text { Repairs/ } \\
\text { renovations }\end{array}$ & $\begin{array}{l}\text { Ordinal variable that indicates the allocation of the income increase to the saving category "Repairs/ renovations } \\
\text { (e.g. of vehicles or real estate)" }\{0-100\} \text {. Derived from the spending allocation question. }\end{array}$ \\
\hline Education & $\begin{array}{l}\text { Ordinal variable that indicates the allocation of the income increase to the saving category "Own education/ } \\
\text { education of members of the household" }\{0-100\} \text {. Derived from the spending allocation question. }\end{array}$ \\
\hline Vacation & $\begin{array}{l}\text { Ordinal variable that indicates the allocation of the income increase to the saving category "Vacation, traveling, } \\
\text { going to a restaurant or other leisure activities", }\{0-100\} \text {. Derived from the spending allocation question. }\end{array}$ \\
\hline Donations/ gifts & $\begin{array}{l}\text { Ordinal variable that indicates the allocation of the income increase to the saving category "Donations/ gifts" }\{0 \text { - } \\
100\} \text {. Derived from the spending allocation question. }\end{array}$ \\
\hline Other & $\begin{array}{l}\text { Ordinal variable that indicates the allocation of the income increase to the saving category "Other" }\{0-100\} \text {. Derived } \\
\text { from the spending allocation question. }\end{array}$ \\
\hline
\end{tabular}




\section{Appendix 3: Display of the income increase for the three treatment groups}

Appendix 3 illustrates the display of the income increase at the example of a respondent with a taxable income of EUR 60,000 to EUR 70,000 and whose income is taxed jointly with a marital partner. Panel A presents a screenshot showing the surveypage of the qualitative MPC question. Panel B shows the altered text displays with respect to the treatment groups.

\section{Panel A: Screenshot of the qualitative MPC questions}

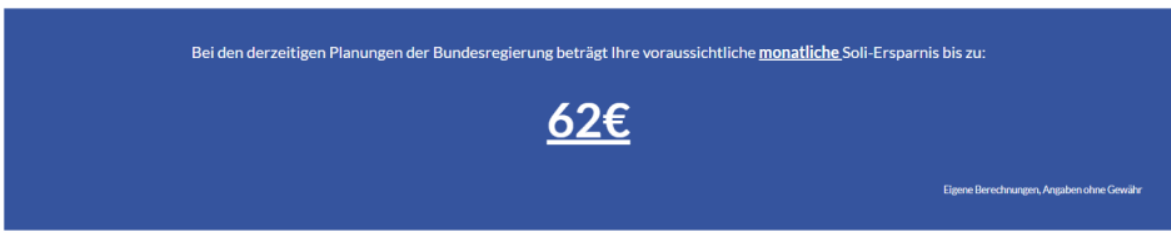

Panel B: Altered texts for the treatment groups

\begin{tabular}{lcc}
\hline Group & \multicolumn{1}{c}{ Displayed Text } & Original displayed text in German \\
\hline Treat: & $\begin{array}{c}\text { According to current planning of the Government, } \\
\text { Monthly }\end{array}$ & $\begin{array}{c}\text { Bei den derzeitigen Planungen der Bundesregierung } \\
\text { beträgt Ihre voraussichtliche } \text { monatliche Soli-Ersparnis } \\
\text { bis zu: }\end{array}$
\end{tabular}

\section{$\underline{62 €}$}

Treat: $\quad$ According to current planning of the Government,

Yearly your expected "Soli"-savings in the next year are up to:

\section{$\underline{744 €}$}

Treat: 10- According to current planning of the Government, Yearly your expected "Soli"-savings in the next 10 years are up to:

\section{$\underline{7,440 €}$}

\section{$\underline{62 €}$}

Bei den derzeitigen Planungen der Bundesregierung beträgt Ihre voraussichtliche Soli-Ersparnis im kommenden Jahr bis zu:

\section{$\underline{744 €}$}

Bei den derzeitigen Planungen der Bundesregierung beträgt Ihre voraussichtliche Soli-Ersparnis in den nächsten 10 Jahren bis zu:

\section{$\underline{7.440 €}$}


Appendix 4: Representativeness of sample

\begin{tabular}{|c|c|c|c|c|c|c|c|c|}
\hline \multirow[t]{2}{*}{ Sample Statistics } & \multicolumn{3}{|c|}{ Whole Sample } & \multicolumn{3}{|c|}{$\mathrm{PHF}$} & & \\
\hline & Mean & $\mathrm{SD}$ & $\mathrm{N}$ & Mean & SD & $\mathrm{N}$ & Diff & T-stat \\
\hline Male & 0.676 & 0.468 & 1,740 & 0.578 & 0.494 & 4,942 & 0.098 & $7.403^{\star \star \star}$ \\
\hline Household size & 2.356 & 1.004 & 1,740 & 2.277 & 1.149 & 4,942 & 0.079 & $2.715^{\star \star *}$ \\
\hline Married & 0.570 & 0.495 & 1,740 & 0.625 & 0.484 & 4,942 & -0.055 & $4.009^{* * *}$ \\
\hline Age & 50.3 & 15.4 & 1,740 & 57.3 & 16.2 & 4,942 & -6.990 & $16.029^{\star \star *}$ \\
\hline College & 0.500 & 0.500 & 1,740 & 0.386 & 0.487 & 4,942 & 0.114 & $8.234^{\star \star *}$ \\
\hline Household income & 5,124 & 2,730 & 1,740 & 4,602 & 2,894 & 4,942 & 522 & $6.746^{\star * *}$ \\
\hline Retired & 0.165 & 0.371 & 1,740 & 0.371 & 0.483 & 4,942 & -0.206 & $18.329^{* * *}$ \\
\hline Self-employed & 0.062 & 0.240 & 1,740 & 0.082 & 0.274 & 4,942 & -0.021 & $2.95^{\star \star \star}$ \\
\hline Financial literacy score & 2.634 & 0.733 & 1,740 & 2.558 & 0.762 & 4,942 & 0.076 & $3.681^{* * *}$ \\
\hline Risk tolerance & 3.457 & 1.507 & 1,740 & 4.114 & 2.212 & 4,935 & -0.657 & $13.709^{\star * *}$ \\
\hline Patience & 4.687 & 1.640 & 1,740 & 4.678 & 2.467 & 4,938 & 0.009 & 0.171 \\
\hline
\end{tabular}

Appendix 5: Descriptive Statistics among treatment groups

\begin{tabular}{|c|c|c|c|c|c|c|c|c|}
\hline \multirow[t]{2}{*}{ Sample Statistics } & \multicolumn{2}{|c|}{ Whole Sample } & \multicolumn{2}{|c|}{ Treat: Monthly } & \multicolumn{2}{|c|}{ Treat: Yearly } & \multicolumn{2}{|c|}{ Treat: 10-yearly } \\
\hline & Mean & SD & Mean & SD & Mean & SD & Mean & SD \\
\hline$\overline{A g e}$ & 50.88 & 15.08 & 51.69 & 15.15 & 51.09 & 15.01 & 49.91 & 15.07 \\
\hline Male & 0.69 & 0.47 & 0.67 & 0.47 & 0.70 & 0.46 & 0.68 & 0.47 \\
\hline Married & 0.60 & 0.49 & 0.63 & 0.48 & 0.59 & 0.49 & 0.58 & 0.49 \\
\hline Household size & 2.37 & 1.00 & 2.39 & 0.98 & 2.41 & 1.02 & 2.30 & 1.00 \\
\hline Taxable income & 66,923 & 34,339 & 66,484 & 34,928 & 66,472 & 34,537 & 67,784 & 33,622 \\
\hline Income increase & 57.11 & 36.89 & 56.35 & 37.67 & 56.11 & 35.95 & 58.82 & 37.07 \\
\hline Tax cut unanticipated & 0.21 & 0.40 & 0.23 & 0.42 & 0.20 & 0.40 & 0.19 & 0.40 \\
\hline College & 0.50 & 0.50 & 0.52 & 0.50 & 0.49 & 0.50 & 0.51 & 0.50 \\
\hline Retired & 0.17 & 0.37 & 0.19 & 0.39 & 0.16 & 0.37 & 0.16 & 0.36 \\
\hline Self-employed & 0.06 & 0.24 & 0.07 & 0.25 & 0.06 & 0.24 & 0.05 & 0.22 \\
\hline Unemployed & 0.02 & 0.13 & 0.02 & 0.15 & 0.02 & 0.14 & 0.01 & 0.10 \\
\hline Homeowner & 0.56 & 0.50 & 0.60 & 0.49 & 0.57 & 0.50 & 0.53 & 0.50 \\
\hline Financial literacy score & 2.67 & 0.69 & 2.62 & 0.73 & 2.70 & 0.68 & 2.68 & 0.66 \\
\hline Risk tolerance & 3.47 & 1.51 & 3.51 & 1.46 & 3.41 & 1.48 & 3.49 & 1.58 \\
\hline Patience & 4.70 & 1.63 & 4.62 & 1.65 & 4.69 & 1.62 & 4.78 & 1.61 \\
\hline Rainy day savings - none & 0.19 & 0.39 & 0.21 & 0.41 & 0.17 & 0.38 & 0.17 & 0.38 \\
\hline Rainy day savings - na & 0.04 & 0.21 & 0.04 & 0.20 & 0.04 & 0.20 & 0.05 & 0.21 \\
\hline Impulsive buying & 1.95 & 1.33 & 2.01 & 1.38 & 1.97 & 1.31 & 1.88 & 1.30 \\
\hline Self-control & 5.18 & 1.46 & 5.18 & 1.47 & 5.20 & 1.41 & 5.17 & 1.50 \\
\hline Observations & \multicolumn{2}{|c|}{1,524} & \multicolumn{2}{|c|}{492} & \multicolumn{2}{|c|}{513} & \multicolumn{2}{|c|}{519} \\
\hline
\end{tabular}


Appendix 6: Regression Analyses: Use of tax rebate (OLS/LPM Regressions) qualitative measure

\begin{tabular}{|c|c|c|c|}
\hline Sample Statistics & $\frac{\text { Spending (qual.) }}{(1)}$ & $\frac{\text { Saving (qual.) }}{(2)}$ & $\frac{\text { Repay debt (qual.) }}{(3)}$ \\
\hline Treat: Yearly & $\begin{array}{c}-0.092^{* * *} \\
(0.030)\end{array}$ & $\begin{array}{l}0.058^{*} \\
(0.030)\end{array}$ & $\begin{array}{l}0.034^{*} \\
(0.019)\end{array}$ \\
\hline Treat: 10 -Yearly & $\begin{array}{c}-0.079^{* * *} \\
(0.029)\end{array}$ & $\begin{array}{c}0.049 \\
(0.030)\end{array}$ & $\begin{array}{c}0.030 \\
(0.019)\end{array}$ \\
\hline Taxable income (log) & $\begin{array}{l}-0.078^{\star} \\
(0.042)\end{array}$ & $\begin{array}{l}0.081^{*} \\
(0.044)\end{array}$ & $\begin{array}{l}-0.003 \\
(0.029)\end{array}$ \\
\hline Income increase (log) & $\begin{array}{l}-0.055^{\star *} \\
(0.022)\end{array}$ & $\begin{array}{l}0.040^{*} \\
(0.022)\end{array}$ & $\begin{array}{c}0.015 \\
(0.015)\end{array}$ \\
\hline Tax cut unanticipated & $\begin{array}{l}-0.005 \\
(0.030)\end{array}$ & $\begin{array}{l}-0.011 \\
(0.031)\end{array}$ & $\begin{array}{c}0.016 \\
(0.021)\end{array}$ \\
\hline Male & $\begin{array}{l}-0.027 \\
(0.028)\end{array}$ & $\begin{array}{c}0.019 \\
(0.028)\end{array}$ & $\begin{array}{l}0.008 \\
(0.017)\end{array}$ \\
\hline Household size & $\begin{array}{c}0.005 \\
(0.014)\end{array}$ & $\begin{array}{l}-0.029^{* *} \\
(0.014)\end{array}$ & $\begin{array}{l}0.024^{\star *} \\
(0.010)\end{array}$ \\
\hline Married & $\begin{array}{l}0.059^{\star} \\
(0.032)\end{array}$ & $\begin{array}{c}-0.078^{* *} \\
(0.033)\end{array}$ & $\begin{array}{c}0.018 \\
(0.020)\end{array}$ \\
\hline Age & $\begin{array}{l}0.015^{\star * *} \\
(0.005)\end{array}$ & $\begin{array}{c}-0.018^{* * *} \\
(0.006)\end{array}$ & $\begin{array}{c}0.002 \\
(0.003)\end{array}$ \\
\hline $\mathrm{Age}^{2}$ & $\begin{array}{l}-0.000^{\star} \\
(0.000)\end{array}$ & $\begin{array}{l}0.000^{* *} \\
(0.000)\end{array}$ & $\begin{array}{l}-0.000 \\
(0.000)\end{array}$ \\
\hline College & $\begin{array}{l}-0.014 \\
(0.024)\end{array}$ & $\begin{array}{l}-0.013 \\
(0.025)\end{array}$ & $\begin{array}{l}0.027^{*} \\
(0.016)\end{array}$ \\
\hline Retired & $\begin{array}{c}0.064 \\
(0.045)\end{array}$ & $\begin{array}{l}-0.078^{*} \\
(0.044)\end{array}$ & $\begin{array}{c}0.014 \\
(0.023)\end{array}$ \\
\hline Self-employed & $\begin{array}{c}0.017 \\
(0.051)\end{array}$ & $\begin{array}{l}-0.023 \\
(0.052)\end{array}$ & $\begin{array}{c}0.006 \\
(0.035)\end{array}$ \\
\hline Unemployed & $\begin{array}{l}-0.067 \\
(0.103)\end{array}$ & $\begin{array}{c}0.002 \\
(0.100)\end{array}$ & $\begin{array}{c}0.065 \\
(0.068)\end{array}$ \\
\hline Homeowner & $\begin{array}{l}0.066^{\star *} \\
(0.028)\end{array}$ & $\begin{array}{c}-0.086^{* * *} \\
(0.029)\end{array}$ & $\begin{array}{c}0.020 \\
(0.020)\end{array}$ \\
\hline Financial literacy score & $\begin{array}{c}0.012 \\
(0.019)\end{array}$ & $\begin{array}{c}0.009 \\
(0.019)\end{array}$ & $\begin{array}{l}-0.021 \\
(0.013)\end{array}$ \\
\hline Risk tolerance & $\begin{array}{l}-0.004 \\
(0.009)\end{array}$ & $\begin{array}{c}0.012 \\
(0.009)\end{array}$ & $\begin{array}{l}-0.008 \\
(0.006)\end{array}$ \\
\hline Patience & $\begin{array}{l}-0.003 \\
(0.008)\end{array}$ & $\begin{array}{l}0.004 \\
(0.008)\end{array}$ & $\begin{array}{l}-0.000 \\
(0.005)\end{array}$ \\
\hline Impulsive buying & $\begin{array}{c}0.015 \\
(0.010)\end{array}$ & $\begin{array}{c}-0.040^{* * *} \\
(0.009)\end{array}$ & $\begin{array}{l}0.025^{\star * *} \\
(0.008)\end{array}$ \\
\hline Self-control & $\begin{array}{c}-0.040^{* * *} \\
(0.009)\end{array}$ & $\begin{array}{l}0.034^{* * *} \\
(0.009)\end{array}$ & $\begin{array}{c}0.006 \\
(0.006)\end{array}$ \\
\hline Rainy day savings - none & $\begin{array}{c}0.048 \\
(0.034)\end{array}$ & $\begin{array}{l}-0.108^{\star \star \star} \\
(0.034)\end{array}$ & $\begin{array}{l}0.060^{* *} \\
(0.026)\end{array}$ \\
\hline Rainy day savings - na & $\begin{array}{l}-0.000 \\
(0.059)\end{array}$ & $\begin{array}{c}0.031 \\
(0.062)\end{array}$ & $\begin{array}{l}-0.031 \\
(0.036)\end{array}$ \\
\hline Constant & $\begin{array}{l}1.090^{* * *} \\
(0.412)\end{array}$ & $\begin{array}{l}-0.026 \\
(0.429)\end{array}$ & $\begin{array}{l}-0.064 \\
(0.282)\end{array}$ \\
\hline Observations & 1,523 & 1,523 & 1,523 \\
\hline $\mathrm{R}^{2}$ & 0.136 & 0.128 & 0.053 \\
\hline
\end{tabular}




\section{References}

Börsch-Supan, A. H., Bucher-Koenen, T., Goll, N., \& Maier, C. (2016). 15 Jahre Riester Eine Bilanz (15 Years of the Riester Pension Scheme - Taking Stock). Working Paper. doi: $10.2139 /$ ssrn. 2879377

Carroll, C. D. (2001). A Theory of the Consumption Function, With and Without Liquidity Constraints. Journal of Economic Perspectives, 15(3), 23-45. doi:10.1257/jep.15.3.23

Carroll, C. D. (2009). Precautionary saving and the marginal propensity to consume out of permanent income. Journal of Monetary Economics, 56(6), 780-790. doi:10.1016/j.jmoneco.2009.06.016

Chambers, V., \& Spencer, M. (2008). Does changing the timing of a yearly individual tax refund change the amount spent vs. saved? Journal of Economic Psychology, 29(6), 856862. doi:10.1016/j.joep.2008.04.001

Christelis, D., Georgarakos, D., Jappelli, T., Pistaferri, L., \& van Rooij, M. (2019). Asymmetric Consumption Effects of Transitory Income Shocks. Economic Journal, 129(622), 2322-2341. doi:10.1093/ej/uez013

Coibion, O., Gorodnichenko, Y., \& Weber, M. (2020). How did U.S. consumers use their stimulus payments? Working Paper. doi:10.3386/w27693

Congdon, W. J., Kling, J. R., \& Mullainathan, S. (2009). Behavioral economics and tax policy. National Tax Journal, 62(3).

Epley, N., \& Gneezy, A. (2007). The framing of financial windfalls and implications for public policy. The Journal of Socio-Economics, 36(1), 36-47. doi:10.1016/j.socec.2005.12.012

Epley, N., Mak, D., \& Idson, L. C. (2006). Erratum: Bonus of rebate?: The impact of income framing on spending and saving. Journal of Behavioral Decision Making, 19(4), 407. doi:10.1002/bdm.546

Feldman, N. E. (2010). Mental accounting effects of income tax shifting. Review of Economics and Statistics, 92(1), 70-86. doi:10.1162/rest.2009.11892 
Gathergood, J., \& Weber, J. (2014). Self-control, financial literacy \& the co-holding puzzle. Journal of Economic Behavior \& Organization, 107, 455-469. doi:10.1016/j.jebo.2014.04.018

Gelman, M. (2020). What drives heterogeneity in the marginal propensity to consume? Temporary shocks vs persistent characteristics. Journal of Monetary Economics. doi:10.1016/j.jmoneco.2020.03.006

German Federal Ministry of Finance. (2019). Ge-setz zur Rück-füh-rung des $\begin{array}{llll}\text { So-li-da-ri-täts-zu-schlags } & 1995 . & \text { Retrieved from }\end{array}$ https://www.bundesfinanzministerium.de/Content/DE/Gesetzestexte/Gesetze_Gesetzesv orhaben/Abteilungen/Abteilung_IV/19_Legislaturperiode/Gesetze_Verordnungen/201912-12-Soli-Rueckfuehrung-G/0-Gesetz.html\#

Graziani, G., van der Klaauw, W., \& Zafar, B. (2016). Workers' spending response to the 2011 payroll tax cuts. American Economic Journal: Economic Policy, 8(4), 124-159. doi:10.1257/pol.20140065

Jappelli, T., \& Pistaferri, L. (2010). The consumption response to income changes. Annual Review of Economics, 2(1), 479-506. doi:10.1146/annurev.economics.050708.142933

Jappelli, T., \& Pistaferri, L. (2014). Fiscal policy and MPC heterogeneity. American Economic Journal: Macroeconomics, 6(4), 107-136. doi:10.1257/mac.6.4.107

Jappelli, T., \& Pistaferri, L. (2020). Reported MPC and unobserved heterogeneity. American Economic Journal: Economic Policy, 12(4), 275-297. doi:10.1257/pol.20180420

Johnson, D. S., Parker, J. A., \& Souleles, N. S. (2006). Household expenditure and the income tax rebates of 2001. American Economic Review, 96(5), 1589-1610. doi:10.1257/aer.96.5.1589

Kalckreuth, U. von, Eisele, M., Le Blanc, J., Schmidt, T., \& Zhu, J. (2012). The PHF: a comprehensive panel survey on household finances and wealth in Germany. Deutsche Bundesbank Discussion Paper. (13), 1-48.

Lusardi, A., \& Mitchell, O. S. (2008). Planning and financial literacy how do women fare? American Economic Review, 98(2), 413-417. doi:10.1257/aer.98.2.413 
Meyll, T., Pauls, T., \& Walter, A. (2020). Why do households leave money on the table? The case of subsidized pension products. Journal of Behavioral Finance, 21(3), 266-283. doi:10.1080/15427560.2019.1692209

Parker, J. A., Souleles, N. S., Johnson, D. S., \& McClelland, R. (2013). Consumer Spending and the Economic Stimulus Payments of 2008. American Economic Review, 103(6), 2530-2553. doi:10.1257/aer.103.6.2530

Sahm, C. R., Shapiro, M. D., \& Slemrod, J. (2010). Household response to the 2008 tax rebate: Survey evidence and aggregate implications. Tax Policy and the Economy, 24(1), 69-110. doi:10.1086/649829

Shapiro, M. D., \& Slemrod, J. (1995). Consumer response to the timing of income: Evidence from a change in tax withholding. American Economic Review, 85(1), 274-283.

Shapiro, M. D., \& Slemrod, J. (2003a). Consumer response to tax rebates. The American economic review, 93(1), 381-396.

Shapiro, M. D., \& Slemrod, J. (2003b). Did the 2001 tax rebate stimulate spending? Evidence from taxpayer surveys. Tax Policy and the Economy, 17, 83-109. doi:10.1086/tpe.17.20140505

Shapiro, M. D., \& Slemrod, J. (2009). Did the 2008 tax rebates stimulate spending? American Economic Review, 99(2), 374-379. doi:10.1257/aer.99.2.374 


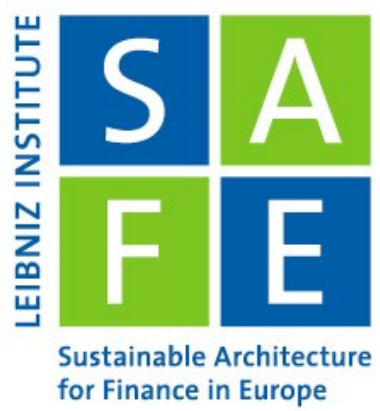

\section{Recent Issues}

No. $307 \quad$ Ester Faia, Andreas Fuster, Vincenzo Pezone, Basit Zafar

No. 306 Aljoscha Janssen, Johannes Kasinger

No. 305 Sabine Bernard, Benjamin Loos, Martin Weber

No. 304 Monica Billio, Andrew W. Lo, Loriana Pelizzon, Mila Getmansky Sherman, Abalfazl Zareei

No. 303 Ankit Kalda, Benjamin Loos, Alessandro Previtero, Andreas Hackethal

No. 302 Tim A. Kroencke, Maik Schmeling, Andreas Schrimpf

No. 301 Di Bu, Tobin Hanspal, Yin Liao, Yong Liu

No. 300 Dennis Gram, Pantelis Karapanagiotis, Jan Krzyzanowski, Marius Liebald, Uwe Walz

No. 299 Ferdinand A. von Siemen

No. 298 Calebe de Roure, Emanuel Moench, Loriana Pelizzon, Michael Schneider

No. 297 Dimitrios Kostopoulos, Steffen Meyer, Charline Uhr

No. 296 Reint Gropp, Thomas Mosk, Steven Ongena, Ines Simac, Carlo Wix

No. 295 Besart Avdiu, Alfons J. Weichenrieder
Biases in Information Selection and Processing: Survey Evidence from the Pandemic

Obfuscation and Rational Inattention in Digitalized Markets

The Disposition Effect in Boom and Bust Markets

Global Realignment in Financial Market Dynamics: Evidence from ETF Networks

Smart (Phone) Investing?

A Within Investor-Time Analysis of New Technologies and Trading Behavior

The FOMC Risk Shift

Risk Taking, Preferences, and Beliefs: Evidence from Wuhan

An Extensible Model for Historical Financial Data with an Application to German Company and Stock Market Data

Motivated Beliefs and the Elderly's Compliance with COVID-19 Measures

OTC Discount

Ambiguity and Investor Behavior

Supranational Rules, National Discretion: Increasing Versus Inflating Regulatory Bank Capital?

Financing Costs and the Efficiency of PublicPrivate Partnerships 